\title{
Molecular phylogenetics and microsatellite analysis reveal a new pathogenic Ceratocystis species in the Asian-Australian clade
}

\author{
F. F. Liu ${ }^{\text {ab }}$, I. Barnes ${ }^{c}$, J. Roux ${ }^{d}$, M. J. Wingfield ${ }^{a}$ and S. F. Chen ${ }^{a b *}$ \\ a Department of Microbiology and Plant Pathology, Forestry and Agricultural Biotechnology Institute (FABI), \\ University of Pretoria, Pretoria 0028, South Africa; \\ ${ }^{b}$ China Eucalypt Research Centre (CERC), Chinese Academy of Forestry (CAF), ZhanJiang, 524022, GuangDong \\ Province, China; \\ ${ }^{\mathrm{C} D e p a r t m e n t}$ of Genetics, FABI, University of Pretoria, Pretoria 0028; and \\ ${ }^{\mathrm{d}}$ Department of Plant and Soil Sciences, FABI, University of Pretoria, Pretoria 0028, South Africa \\ *E-mail: shuaifei.chen@gmail.com
}

\begin{abstract}
The ascomycete genus Ceratocystis has a broad geographic distribution and includes pathogens of a wide range of mostly woody hosts. Black rot of Colocasia esculenta (taro), a popular cultivated root crop in China, is caused by a species of Ceratocystis broadly treated as $C$. fimbriata sensu lato. Recently, isolates of Ceratocystis were obtained from black rot lesions on $C$. esculenta corms in two Chinese provinces. Sequence comparison of the ITS, partial $\beta$-tubulin, TEF-1 $\alpha$, MS204 and RPBIl gene regions were used to identify these isolates and compare them to other Ceratocystis species. Furthermore, the diversity of Ceratocystis species in the Asian-Australian clade (AAC) was investigated using 23 microsatellite markers. Results showed that the isolates from $C$. esculenta represent a novel species, which is morphologically and phylogenetically different to closely related species in the AAC, and is described here as Ceratocystis changhui sp. nov. In microsatellite analyses, this new species also emerged as distinct from others in the AAC. Inoculation tests showed that $C$. changhui sp. nov. is a virulent pathogen of $C$. esculenta corms, but produces only small lesions on Eucalyptus grandis and Eriobotrya japonica.
\end{abstract}

\section{Introduction}

Species in the Ceratocystidaceae (Microascales, Ascomycota) occur on a wide range of hosts with a broad geographic distribution (De Beer et al., 2014). The family encompasses 11 genera, Ambrosiella, Berkeleyomyces, Bretziella, Ceratocystis, Chalaropsis, Davidsoniella, Endoconidiophora, Huntiella, Meredithiella, Phialophoropsis and Thielaviopsis, which include plant pathogens, insect associates and the causal agents of sap stain in lumber (De Beer et al., 2014, 2017; Nel et al., 2017). Ceratocystis is the largest genus in the family including many important plant pathogens such as those of fruit and forest trees as well as tuber crops (Kile, 1993; Engelbrecht \& Harrington, 2005; Roux \& Wingfield, 2009; Al Adawi et al., 2013). These pathogens cause a wide range of symptoms such as staining of vascular tissues, stem and branch cankers, wilt, and black rot of tubers (Kile, 1993; Roux \& Wingfield, 2009). The genus is typified by $C$. fimbriata, which was originally described causing rot of Ipomoea batatas (sweet potato; Halsted, 1890). 
Ceratocystis species are broadly considered to reside in four well-supported phylogenetic lineages linked to geographic regions. Authors investigating the biogeography of these fungi have used somewhat different notations for these clades (Harrington, 2000; Mbenoun et al., 2014; Li et al., 2016, 2017). For the present study, the groupings provided by Li et al. (2017) are used. Thus, the clade accommodating the type species $C$. fimbriata sensu stricto is referred to as the Latin American clade (LAC) and isolates that form the basis of the present study are the Asian-Australian clade (AAC).

Recent studies based on multigene DNA sequence phylogenies, morphology and ecology have suggested that species concepts in Ceratocystis require re-evaluation (De Beer et al., 2014; Mbenoun et al., 2014; Fourie et al., 2015). For example, a recent study by Fourie et al. (2015) showed that several cryptic species could be recognized in the LAC. Using the internal transcribed spacer (ITS) gene region, selected as the universal barcoding region for fungal species identification (Schoch et al., 2012), is problematic for some species in the LAC and AAC of Ceratocystis because different ITS haplotypes can occur in a single Ceratocystis isolate (Al Adawi et al., 2013; Harrington et al., 2014; Fourie et al., 2015; Liu et al., 2015). Delineation of taxonomic boundaries, particularly for Ceratocystis species in the LAC, has differed amongst researchers; some define species specifically based on phylogenetic inference (De Beer et al., 2014; Fourie et al., 2015), whereas others have applied a broader population-level concept, particularly for C. fimbriata sensu lato (Harrington et al., 2014; Oliveira et al., 2015a).

Taro (Colocasia esculenta) belongs to the family Araceae and is a highly polymorphic species (Chair et al., 2016). It is a staple food source in many localities in the humid tropics and subtropics and extends to the temperate zones of East Asia, southern Africa, Australia and New Zealand (Chair et al., 2016). The tubers of these plants are susceptible to a disease commonly referred to as black rot caused by Ceratocystis fimbriata s.l. (Harrington et al., 2005; Thorpe et al., 2005; Huang et al., 2008; Li et al., 2017). The first report of a Ceratocystis species causing disease on the Araceae was in 1939 when a post-harvest disease on C. esculenta was reported from Japan (Shimizu, 1939). There have subsequently been several reports of this disease from many countries of the world including North and South America and South-east Asia (Harrington et al., 2005; Thorpe et al., 2005; Huang et al., 2008; Li et al., 2017). A disease similar to black rot also occurs on related tuber crops in the Araceae, such as on species of Alocasia, Syngonium and Xanthosoma (Uchida \& Aragaki, 1979; Thorpe et al., 2005; Li et al., 2017).

There have been many reports of Ceratocystis spp. in the LAC causing diseases on several hosts in China. These include black rot on I. batatas (Sy, 1956) and C. esculenta in YunNan Province (Huang et al., 2008), a wilt disease on Punica granatum (pomegranate) in YunNan and SiChuan Provinces (Huang et al., 2003; Xu et al., 2011) and these fungi have also been collected from recently harvested stumps of Eucalyptus in GuangDong Province (Chen et al., 2013). Black rot on sweet potato is caused by C. fimbriata s.s. (Sy, 1956), a pathogen that has been spread globally (Harrington et al., 2015). Isolates from Colocasia and Punica have been treated as C. fimbriata s.I. (Harrington et al., 2015; Li et al., 2016), but have identical ITS sequences to isolates representing a species known as $C$. manginecans, which is a serious tree pathogen in various countries of South-east Asia (Fourie et al., 2015, 2016). 
There have also been several reports of Ceratocystis sp. in the AAC from China. These include $C$. cercfabiensis described from stumps of Eucalyptus in FuJian, GuangDong, GuangXi and HaiNan Provinces in southern China (Liu et al., 2015), C. collisensis from Cunninghamia lanceolata in FuJian Province (Liu et al., 2015), and isolates representing an undescribed Ceratocystis sp. ' $Y$ ' (Li et al., 2017) from C. esculenta (BPI 596161, BPI 596162) imported into the USA from China in 1949 (Thorpe et al., 2005; Li et al., 2017) and including isolates (C3371-C3376) collected from leaves or twigs of Eucalyptus trees in YunNan Province (Li et al., 2017). In addition, isolates of Ceratocystis from Eriobotrya japonica (loquat; E2-2) and Eucalyptus (PY1-1, PY2-1) have been reported from YunNan Province in China and broadly treated as C. fimbriata s.I. (Li et al., 2014a,b). However, the ITS sequences of the latter isolates have $99 \%$ similarity to those of $C$. uchidae, a newly described species in the AAC group (Li et al., 2017) and 100\% similarity to those of the undescribed Ceratocystis sp. ' $Y$ ' (Li et al., 2014a,b).

Recent surveys for Ceratocystis species on various plants in China have yielded isolates from C. esculenta corms in the YunNan and ShanDong Provinces. Preliminary sequence data, based on ITS sequences, suggested that these isolates are phylogenetically similar to those obtained from E. japonica and Eucalyptus species in YunNan Province that grouped in the AAC (Li et al., 2014a,b, 2017), and also similar to those of the undescribed Ceratocystis sp. ' $Y$ ' (Li et al., 2017). The aim of this study was to identify a collection of isolates from C. esculenta in YunNan and ShanDong Provinces, based on phylogenetic analyses of DNA sequences for multiple gene regions and morphological characteristics. Genetic analyses of allele sizes, determined using microsatellite markers, provided deeper, population level information regarding these fungi. The pathogenicity of isolates was tested on corms of C. esculenta as well as on stems of E. japonica and Eucalyptus grandis saplings.

\section{Materials and methods}

\section{Fungal isolates}

Diseased C. esculenta corms were collected at farmer's markets in the YunNan and ShanDong Provinces of China in August 2014 and May 2015, respectively. Ascomata of Ceratocystis species were common on the surfaces of wounds (Fig. 1a,b) and in some cases, the entire corms were rotten. Cultures were made by transferring ascospore masses from the tips of the ascomata to $2 \%$ malt extract agar (MEA; $20 \mathrm{~g}$ malt extract and $20 \mathrm{~g}$ agar per litre of water). Cultures were incubated at $25^{\circ} \mathrm{C}$ for $4-7$ days and then purified by making single hyphal tip transfers to fresh MEA plates. 

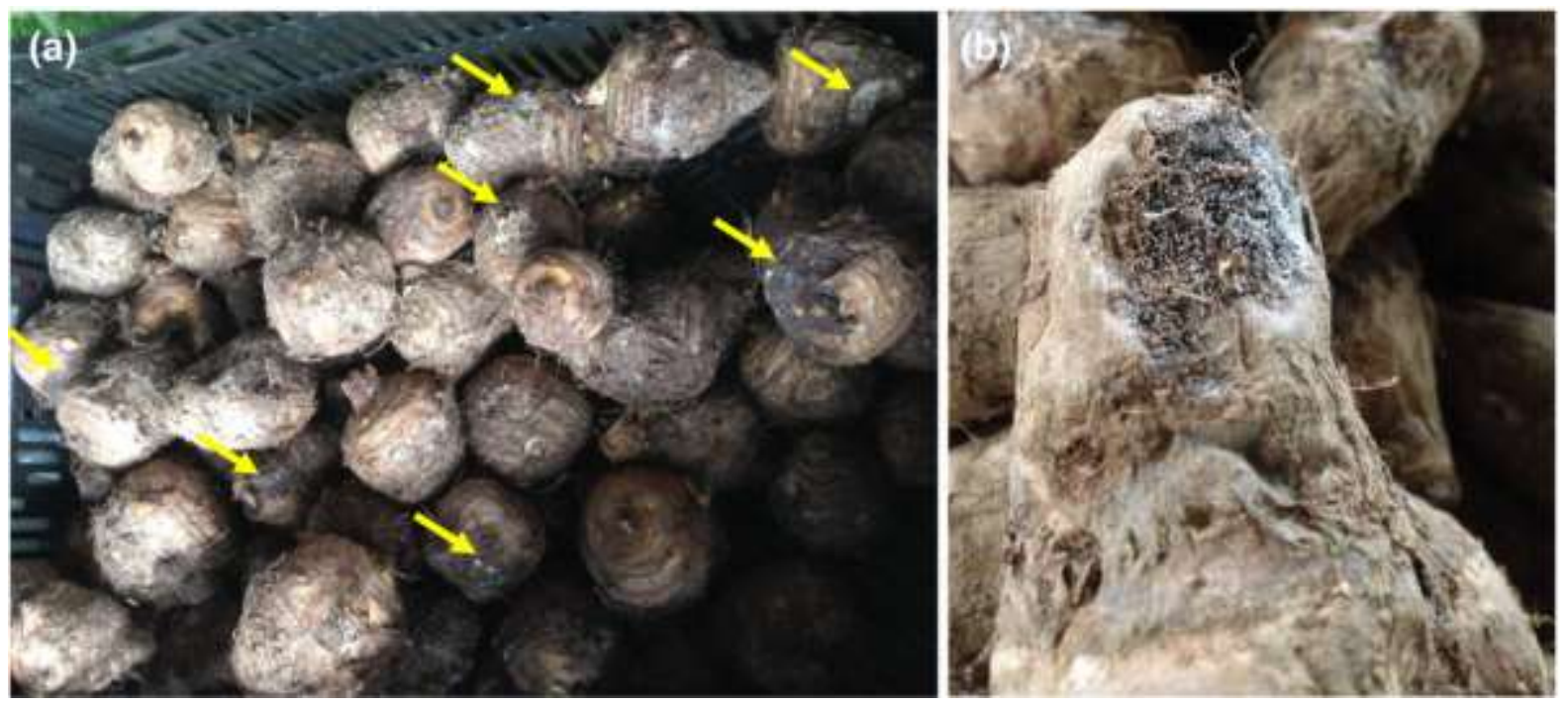

Figure 1. Disease symptoms caused by Ceratocystis changhui on Colocasia esculenta (taro) in YunNan Province, China; (a) diseased C. esculenta corms with the fungal mycelia growing from rotten sites (shown by arrows); (b) fruiting structures with ascospore masses on the black rot lesion of $C$. esculenta.

All 31 isolates obtained in this study were deposited in the culture collection of the China Eucalypt Research Centre (CERC), Chinese Academy of Forestry (CAF), ZhanJiang, GuangDong Province, China and in the Culture Collection (CMW) of the Forestry and Agricultural Biotechnology Institute (FABI), University of Pretoria, South Africa.

Representative isolates of a newly described taxon were deposited with the Westerdijk Fungal Biodiversity Institute (CBS), Utrecht, Netherlands. Dried specimens were deposited with the National Collection of Fungi (PREM), Pretoria, South Africa.

This study also included six Eucalyptus isolates (C3371-C3376) of Ceratocystis sp. ' $\mathrm{Y}$ ' (Li et al., 2017) supplied by Professor T. Harrington, Department of Plant Pathology and Microbiology, lowa State University (Tables 1 \& S1). In addition, isolates of 11 other Ceratocystis species in the AAC were used. These included 40 isolates of $C$. cercfabiensis that were collected previously from Eucalyptus trees in five provinces of China (Liu et al., 2015), four isolates of $C$. collisensis, and two ex-type isolates of each of nine Ceratocystis species (C. atrox, C. corymbiicola, C. ficicola, C. larium, C. obpyriformis, C. piriliformis, C. polychroma, C. polyconidia, C. uchidae; Table S1).

\section{Sequencing and multigene phylogenetic analyses}

DNA was extracted from all above-mentioned isolates for further analyses. Cultures from single hyphal tips grown on $2 \%$ MEA for 2-3 weeks at $25^{\circ} \mathrm{C}$ were used for extraction. Mycelia were scraped from the surfaces of MEA plates using a sterile scalpel and transferred to $2 \mathrm{~mL}$ Eppendorf tubes. DNA was extracted using the method described by Möller et al. (1992). DNA concentrations were determined using a ND-1000 spectrophotometer (Nano Drop Technologies, Thermo Scientific) and dilutions made to approximately $50 \mathrm{ng} \mathrm{LL}^{-1}$.

The 31 isolates from $C$. esculenta corms collected in the present study and the six isolates of Ceratocystis sp. ' $Y$ ' from Eucalyptus were subjected to PCR amplification and subsequent sequencing of five gene regions. These comprised the ITS regions 1 and 2, including the 5.8S 
Table 1 List of Ceratocystis isolates included in this study

\begin{tabular}{|c|c|c|c|c|c|c|c|c|c|c|c|}
\hline \multirow[b]{2}{*}{ Species } & \multirow[b]{2}{*}{ CMW no. } & \multirow[b]{2}{*}{ CERC no. } & \multirow[b]{2}{*}{ Other no. } & \multicolumn{5}{|c|}{ GenBank accession no. } & \multirow[b]{2}{*}{ Host (or substrate) } & \multirow[b]{2}{*}{ Collectors } & \multirow[b]{2}{*}{ Geographic origin } \\
\hline & & & & ITS & $\beta$-tubulin & $T E F-1 \alpha$ & MS204 & $R P B \|$ & & & \\
\hline C. albifundus & CMW 4068 & & CBS 128992 & DQ520638 & EF070429 & EF070400 & KY643987 & KY644041 & Acacia mearnsii & J. Roux & South Africa \\
\hline C. atrox & CMW 19383 & & CBS 120517 & EF070414 & EF070430 & EF070402 & KY643975 & KY644029 & Eucalyptus grandis & M.J. Wingfield & Australia \\
\hline C. atrox $^{\top}$ & CMW 19385 & & CBS 120518 & EF070415 & EF070431 & EF070403 & KY643976 & KY644030 & E. grandis & M.J. Wingfield & Australia \\
\hline C. cercfabiensis ${ }^{\top}$ & CMW 43029 & CERC $2170^{a}$ & CBS 139654 & $\begin{array}{l}\text { KP727592, } \\
\text { KP727593, } \\
\text { KP727594 }\end{array}$ & KP727618 & KP727643 & KY643963 & KY644016 & Eucalyptus sp. & S.F. Chen \& F.F. Liu & HaiNan, China \\
\hline C. cercfabiensis & CMW 42515 & CERC $2345^{a}$ & CBS 139655 & KP727588 & KP727596 & KP727621 & KY643965 & KY644018 & Eucalyptus sp. & S.F. Chen \& F.F. Liu & GuangXi, China \\
\hline C. cercfabiensis & CMW 42795 & CERC $2687^{a}$ & CBS 139656 & KP727583 & KP727619 & KP727644 & KY643968 & KY644022 & Eucalyptus sp. & S.F. Chen \& F.F. Liu & GuangDong, China \\
\hline C. cercfabiensis & CMW 42512 & CERC 2335 & & $\begin{array}{l}\text { KP727583, } \\
\text { KP727589, } \\
\text { KP727590, } \\
\text { KP727591 }\end{array}$ & KP727607 & KP727632 & KY643964 & KY644017 & Eucalyptus sp. & S.F. Chen \& F.F. Liu & GuangXi, China \\
\hline C. cercfabiensis & CMW 42736 & CERC 2576 & & $\begin{array}{c}\text { KP727583, } \\
\text { KP727584, } \\
\text { KP727585 }\end{array}$ & KP727600 & KP727625 & KY643966 & KY644019 & Eucalyptus sp. & S.F. Chen \& F.F. Liu & GuangDong, China \\
\hline C. cercfabiensis & CMW 42741 & CERC 2581 & & $\begin{array}{c}\text { KP727586, } \\
\text { KP727588, } \\
\text { KP727587 }\end{array}$ & KP727601 & KP727626 & KY643967 & KY644020 & Eucalyptus sp. & S.F. Chen \& F.F. Liu & GuangDong, China \\
\hline C. changhui & CMW 43268 & CERC $3601^{a}$ & & KY643883 & KY643913 & KY643935 & KY643956 & KY644009 & $\begin{array}{l}\text { Colocasia } \\
\text { esculenta }\end{array}$ & S.F. Chen & YunNan, China \\
\hline C. changhui & CMW 43272 & CERC $3605^{a b}$ & CBS 139798 & KY643886 & KY643915 & KY643937 & KY643958 & KY644011 & C. esculenta & S.F. Chen & YunNan, China \\
\hline C. changhui & CMW 43273 & CERC $3606^{\mathrm{ab}}$ & CBS 139799 & KY643889 & KY643916 & KY643938 & KY643959 & KY644012 & C. esculenta & S.F. Chen & YunNan, China \\
\hline C. changhui & CMW 43280 & CERC $3614^{a}$ & & KY643887 & KY643918 & KY643940 & KY643961 & KY644014 & C. esculenta & S.F. Chen & YunNan, China \\
\hline C. changhui ${ }^{\top}$ & CMW 43281 & CERC $3615^{\mathrm{ab}}$ & CBS 139797 & KY643884 & KY643919 & KY643941 & KY643962 & KY644015 & C. esculenta & S.F. Chen & YunNan, China \\
\hline C. changhui & CMW 46111 & CERC 7516 & & KY643890 & KY643906 & KY643928 & KY643950 & KY644003 & C. esculenta & S.F. Chen & ShanDong, China \\
\hline C. changhui & CMW 46112 & CERC 7527 & & KY643891 & KY643907 & KY643929 & KY643951 & KY644004 & C. esculenta & S.F. Chen & ShanDong, China \\
\hline C. changhui & CMW 46113 & CERC 7530 & & KY643892 & KY643908 & KY643930 & KY643952 & KY644005 & C. esculenta & S.F. Chen & ShanDong, China \\
\hline C. changhui & CMW46116 & CERC 7543 & & KY643895 & KY643911 & KY643933 & KY643954 & KY644007 & C. esculenta & S.F. Chen & ShanDong, China \\
\hline C. collisensis ${ }^{\top}$ & CMW 42552 & CERC 2459 & CBS 139679 & KP727578 & KP727614 & KP727639 & KY643970 & KY644024 & $\begin{array}{l}\text { Cunninghamia } \\
\text { lanceolata }\end{array}$ & S.F. Chen \& F.F. Liu & FuJian, China \\
\hline C. collisensis & CMW 42554 & CERC 2466 & CBS 139647 & KP727580 & KP727615 & KP727640 & KY643972 & KY644026 & C. lanceolata & S.F. Chen \& F.F. Liu & FuJian, China \\
\hline C. corymbiicola ${ }^{\top}$ & CMW 29120 & & CBS 127215 & HM071902 & HM071914 & HQ236453 & KY643983 & KY644037 & $\begin{array}{c}\text { Corymbia } \\
\text { variegata }\end{array}$ & G.K. Nkuekam & Australia \\
\hline C. corymbiicola & CMW 29349 & & CBS 127216 & HM071919 & HQ236455 & HM071905 & KY643984 & KY644038 & $\begin{array}{l}\text { Eucalyptus } \\
\text { pilularis }\end{array}$ & G.K. Nkuekam & Australia \\
\hline C. ficicola ${ }^{\top}$ & CMW 38543 & & $\begin{array}{l}\text { C1355, } \\
\text { BPI } 843724\end{array}$ & NR_119410 & KY685077 & KY316544 & KY685080 & KY685082 & Ficus carica & Y. Kajitani & Japan \\
\hline C. ficicola & CMW 38544 & & & KY685076 & KY685078 & KY685079 & KY685081 & KY685083 & F. carica & Y. Kajitani & Japan \\
\hline C. fimbriata & CMW 1547 & & CBS 123010 & AF264904 & EF070443 & EF070395 & KJ601577 & KJ601613 & Ipomoea batatas & E.C.H. McKenzie & Papua New Guinea \\
\hline C. fimbriata & CMW 15049 & & CBS 141.37 & DQ520629 & EF070442 & EF070394 & N/A & $N / A$ & 1. batatas & C.F. Andrus & USA \\
\hline
\end{tabular}




\begin{tabular}{|c|c|c|c|c|c|c|c|c|c|c|c|}
\hline \multirow[b]{2}{*}{ Species } & \multirow[b]{2}{*}{ CMW no. } & \multirow[b]{2}{*}{ CERC no. } & \multirow[b]{2}{*}{ Other no. } & \multicolumn{5}{|c|}{ GenBank accession no. } & \multirow[b]{2}{*}{ Host (or substrate) } & \multirow[b]{2}{*}{ Collectors } & \multirow[b]{2}{*}{ Geographic origin } \\
\hline & & & & ITS & $\beta$-tubulin & $T E F-1 \alpha$ & MS204 & $R P B \|$ & & & \\
\hline C. fimbriata s.l. & & & PY2-1 & KF963101 & $\mathrm{N} / \mathrm{A}$ & $\mathrm{N} / \mathrm{A}$ & N/A & N/A & $\begin{array}{l}\text { Eriobotrya } \\
\text { japonica }\end{array}$ & J. Li & YunNan, China \\
\hline C. fimbriata s.I. & & & PY1-1 & KF963102 & $\mathrm{N} / \mathrm{A}$ & N/A & N/A & N/A & E. japonica & J. Li & YunNan, China \\
\hline C. fimbriata s.I. & & & E2-2 & KJ511481 & $\mathrm{N} / \mathrm{A}$ & N/A & N/A & N/A & Eucalyptus sp. & J. Li & YunNan, China \\
\hline Ceratocystis sp. Y & & & BPI596161 & AY526304 & $\mathrm{N} / \mathrm{A}$ & $\mathrm{N} / \mathrm{A}$ & $N / A$ & N/A & C. esculenta & Li et al. & $\begin{array}{l}\text { Import from } \\
\text { China in } 1949\end{array}$ \\
\hline Ceratocystis sp. Y & & & BPI596162 & AY526305 & $\mathrm{N} / \mathrm{A}$ & N/A & N/A & N/A & C. esculenta & Li et al. & $\begin{array}{l}\text { Import from } \\
\text { China in } 1949\end{array}$ \\
\hline Ceratocystis sp. $\mathrm{Y}^{\mathrm{C}}$ & CMW 49317 & & E2-1-1, С3371 & KY643879 & KY643900 & KY643922 & KY643944 & KY643997 & Eucalyptus sp. & Li et al. & YunNan, China \\
\hline Ceratocystis sp. $\mathrm{Y}^{\mathrm{c}}$ & CMW 49318 & & E2-1-2, C3372 & KY306682 & KY643901 & KY643923 & KY643945 & KY643998 & Eucalyptus sp. & Li et al. & YunNan, China \\
\hline Ceratocystis sp. $Y^{c}$ & CMW 49319 & & E2-2-1, С3373 & KY643880 & KY643902 & KY643924 & KY643946 & KY643999 & Eucalyptus sp. & Li et al. & YunNan, China \\
\hline Ceratocystis sp. $Y^{c}$ & CMW 49320 & & E2-2-2, С3374 & KJ511481 & KY643903 & KY643925 & KY643947 & KY644000 & Eucalyptus sp. & Li et al. & YunNan, China \\
\hline Ceratocystis sp. $Y^{c}$ & CMW 49321 & & E2-3-1, С3375 & KY643881 & KY643904 & KY643926 & KY643948 & KY644001 & Eucalyptus sp. & Li et al. & YunNan, China \\
\hline Ceratocystis sp. $Y^{c}$ & CMW 49322 & & E2-3-2, С3376 & KY643882 & KY643905 & KY643927 & KY643949 & KY644002 & Eucalyptus sp. & Li et al. & YunNan, China \\
\hline C. larium $^{\top}$ & CMW 25434 & & CBS 122512 & EU881906 & EU881894 & EU881900 & KY643981 & KY644035 & Styrax benzoin & M.J. Wingfield & Indonesia \\
\hline C. larium & CMW 25435 & & CBS 122606 & EU881907 & EU881895 & EU881901 & KY643982 & KY644036 & S. benzoin & M.J. Wingfield & Indonesia \\
\hline C. obpyriformis & CMW 23807 & & CBS 122608 & EU245004 & EU244976 & EU244936 & KY643977 & KY644031 & A. mearnsii & R.N. Heath & South Africa \\
\hline C. obpyriformis ${ }^{\top}$ & CMW 23808 & & CBS 122511 & EU245003 & EU244975 & EU244935 & KY643978 & KY644032 & A. mearnsii & R.N. Heath & South Africa \\
\hline C. pirilliformis & CMW 6569 & & & AF427104 & DQ371652 & AY528982 & KY643985 & KY644039 & Eucalyptus nitens & M.J. Wingfield & Australia \\
\hline C. pirilliformis ${ }^{\top}$ & CMW 6579 & & CBS 118128 & AF427105 & DQ371653 & AY528983 & KJ601594 & KJ601630 & E. nitens & M.J. Wingfield & Australia \\
\hline C. polychroma ${ }^{\top}$ & CMW 11424 & & CBS 115778 & AY528970 & AY528966 & AY528978 & KY643973 & KY644027 & $\begin{array}{l}\text { Syzygium } \\
\text { aromaticum }\end{array}$ & M.J. Wingfield & Indonesia \\
\hline C. polychroma & CMW 11436 & & CBS 115777 & AY528971 & AY528967 & AY528979 & KY643974 & KY644028 & S. aromaticum & M.J. Wingfield & Indonesia \\
\hline C. polyconidia ${ }^{\top}$ & CMW 23809 & & CBS 122289 & EU245006 & EU244978 & EU244938 & KY643979 & KY644033 & A. mearnsii & R.N. Heath & South Africa \\
\hline C. polyconidia & CMW 23818 & & CBS 122290 & EU245007 & EU244979 & EU244939 & KY643980 & KY644034 & A. mearnsii & R.N. Heath & South Africa \\
\hline C. uchidae $^{\top}$ & CMW 48505 & & $\begin{array}{l}\text { CBS } 115164, \\
\text { C1714 }\end{array}$ & AY526306 & KY643899 & KY643921 & KY643943 & KY643996 & C. esculenta & Li et al. & Hawaii, USA \\
\hline C. uchidae & CMW 48501 & & $\begin{array}{l}\text { CBS } 114720 \text {, } \\
\text { C1715 }\end{array}$ & AY526307 & KY643898 & KY643920 & KY643942 & KY643995 & C. esculenta & Li et al. & Hawaii, USA \\
\hline C. uchidae & & & C1931 & AY526308 & $\mathrm{N} / \mathrm{A}$ & HM569618 & N/A & N/A & $\begin{array}{l}\text { Xanthosoma } \\
\text { sagittifolium }\end{array}$ & Li et al. & Fiji \\
\hline $\begin{array}{l}\text { Davidsoniella } \\
\text { virescens }\end{array}$ & CMW 11164 & & CBS 123166 & DQ520639 & EF070441 & EF070413 & N/A & N/A & Fagus americanum & D. Houston & USA \\
\hline
\end{tabular}

The type isolate of the species. CMW = Culture collection of the Forestry and Agricultural Biotechnology Institute, University of Pretoria, Pretoria, South Africa; CERC = Culture collection of China Eucalypt Research Centre, Chinese Academy of Forestry, ZhanJiang, GuangDong Province, China; CBS = the Westerdijk Fungal Biodiversity Institute, Utrecht, Netherlands.

Isolates indicated in bold are newly identified and described in this study. GenBank accession numbers indicated in bold were generated in this study.

asolates used for the pathogenicity tests.

bIsolates used for the growth study.

Identified as C. changhui in this study. 
rRNA gene, partial $\beta$-tubulin gene (BT1), partial translation elongation factor-1 $\alpha$ gene (TEF$1 \alpha$ ), MS204 and RPBIl gene regions. The primers used were ITS1 and ITS4 (White et al., 1990) for the ITS region, Bt1a and Bt1b (Glass \& Donaldson, 1995; Van Wyk et al., 2011; Mbenoun et al., 2014) for the BT1 gene, TEF1F and TEF2R (Jacobs et al., 2004) for the TEF$1 \alpha$ gene, MS204F.ceratoB and MS204R.ceratoB (Fourie et al., 2015) for the MS204 gene and RPB2-5Fb and RPB2-7Rb (Duong et al., 2012) for the RPBll gene.

Amplification reactions for the five gene regions were conducted in $25 \mu \mathrm{L}$ final volumes as described by Liu et al. (2015). The PCR programme for amplification of the ITS, BT1 and TEF1- $\alpha$ gene regions was carried out as described by Liu et al. (2015). An extended-PCR programme was used for the RPB/l gene region as follows: $95^{\circ} \mathrm{C}$ for $5 \mathrm{~min},\left(95^{\circ} \mathrm{C}\right.$ for $30 \mathrm{~s}$, $59{ }^{\circ} \mathrm{C}$ for $45 \mathrm{~s}, 72{ }^{\circ} \mathrm{C}$ for $\left.90 \mathrm{~s}\right) \times 10$ cycles, $\left(95^{\circ} \mathrm{C}\right.$ for $30 \mathrm{~s}, 59^{\circ} \mathrm{C}$ for $45 \mathrm{~s}, 72{ }^{\circ} \mathrm{C}$ for $90 \mathrm{~s}+5 \mathrm{~s}$ per cycle increase) $\times 30$ cycles and $60^{\circ} \mathrm{C}$ for $35 \mathrm{~min}$. The PCR programme used for the MS204 gene region included an initial denaturation step at $95{ }^{\circ} \mathrm{C}$ for $5 \mathrm{~min}$ followed by 35 cycles of $30 \mathrm{~s}$ at $95^{\circ} \mathrm{C}, 45 \mathrm{~s}$ at $56^{\circ} \mathrm{C}$ and $60 \mathrm{~s}$ at $72{ }^{\circ} \mathrm{C}$, and a final extension step at $72{ }^{\circ} \mathrm{C}$ for $10 \mathrm{~min}$.

PCR products were purified by gel filtration through 6\% Sephadex G-50 (Sigma). Sequencing reactions were conducted using both the forward and reverse primers for each gene region using the ABI PRISM BigDye Terminator Cycle Sequencing Ready Reaction kit v. 3.1 (Applied BioSystems). An ABI PRISM 3100 Autosequencer (Applied BioSystems) was used to generate the sequences.

Raw sequence data were edited and assembled using geneious v. 7.0. Preliminary identification was made by submitting sequences to the blast network service of the National Center for Biotechnology Information (NCBI) (http://www.ncbi.nlm.nih.gov) in order to search for closely related species. Preliminary sequence data, based on the ITS sequences, suggested that isolates collected in this study were closely related to Ceratocystis species in the AAC. Sequence data for the type strains of Ceratocystis species in the AAC were downloaded from GenBank (http://www.ncbi.nlm.nih.gov). Because the sequences for MS204 and RPBII gene regions for Ceratocystis isolates in the AAC were not available in GenBank, the ex-type cultures of relevant Ceratocystis species were sequenced to obtain the required datasets (Table 1). Sequences were aligned using mafft v. 7 (http://mafft.cbrc.jp/align-ment/server; Katoh et al., 2002), and then confirmed manually in mega v. 7.

For tree construction, maximum parsimony (MP) and maximum likelihood (ML) analyses were applied to each gene dataset as well as to a five-gene combined dataset. Before conducting combined analyses for sequences of the five gene regions, a partition homogeneity test (PHT) implemented in paup, was used to determine whether conflict existed between the datasets (Farris et al., 1995; Huelsenbeck et al., 1996). MP analyses were performed using paup v. 4.0b10* (Swofford, 2003). Uninformative characters were excluded and all informative characters were unordered and of equal weight, and gaps coded as a fifth character state. The most parsimonious trees (MPTs) were generated using a heuristic tree search criterion, including random stepwise addition of 1000 replicates and tree-bisection-reconstruction (TBR) branch-swapping. Statistical support for branch nodes in the MPTs was assessed with 1000 bootstrap replicates. Other parameters estimated for 
MPTs included the tree length ( $T L)$, retention index (RI), consistency index $(\mathrm{Cl})$ and rescaled consistency indices (RC).

Maximum likelihood (ML) analyses were conducted for each dataset with PhyML v. 3.1 (Guindon \& Gascuel, 2003). The most appropriate model for each dataset was obtained using the software package jModeltest v. 1.2.5 (Posada, 2008). Confidence levels for the nodes were determined using 1000 bootstrap replicates. Final consensus trees were viewed in mega v. 7 (Tamura et al., 2007). For both MP and ML analyses, Ceratocystis albifundus (CMW 4068) was used as the out-group taxon for the BT1, TEF-1 $\alpha, M S 204$, RPBII and the combined datasets. For the ITS gene region, Davidsoniella virescens (CMW 11164) was used as the out-group.

\section{Microsatellite amplification and genetic analyses}

\section{Allele scoring and genotyping}

The genetic diversity of 99 isolates, including 31 isolates collected from C. esculenta corms in this study, six isolates of Ceratocystis sp. ' $Y$ ' (Li et al., 2017), 40 isolates of $C$. cercfabiensis (Liu et al., 2015), as well as 22 isolates for 10 other Ceratocystis species in the AAC (Table S1), was determined using 32 previously developed microsatellite markers (Barnes et al., 2001; Steimel et al., 2004; Fourie et al., 2016). Amplification reactions were performed in a total volume of $25 \mu \mathrm{L}$ as described above, using the same conditions described by the authors that had developed the markers with slight modifications in annealing temperatures.

The microsatellite amplicons were analysed in three panels with GeneScan on an ABI 3500xI Autosequencer (Thermo Fisher Scientific). GeneScan Liz500(-250) size standard (Applied Biosystems) was used as the internal size standard. GeneScan data were analysed with GeneMapper v. 4.1 software (Applied Biosystems) to score fragment lengths as alleles. The combination of alleles for each isolate provided a multilocus genotype (MLG).

The MLGs of all 99 isolates in the AAC were compared to detect novel and shared genotypes as well as private alleles in the species. Isolates of the same species that shared identical MLGs were considered to be clones. A clone-corrected dataset was assembled in which each haplotype was represented once per species. This clone-corrected dataset was used for most of the analyses unless otherwise mentioned. popgene v. 1.31 (Yeh et al., 1999) was used to calculate the total number of alleles, the number of private alleles for each locus, and the allelic frequencies for each species.

\section{UPGMA analyses}

To assess relationships among the isolates collected from $C$. esculenta corms in this study as well as for the Ceratocystis species in the AAC, all the polymorphic microsatellite markers were used to determine their MLGs. The genetic distance between all the species in the AAC and the proportion of shared alleles were determined with the software populations $v$. 1.2.32 (Langella, 1999), using a Nei's minimum distance measure and a distance matrix. Subsequently, an unweighted pair group method with arithmetic mean (UPGMA), total 
character difference tree was constructed in the same software to visualize the calculated distances, using 1000 bootstrap replications to ensure the results are statistically significant.

\section{Morphological comparisons}

Isolates collected from $C$. esculenta in this study were characterized based on structure morphology, culture morphology and optimal temperature for growth on $2 \%$ MEA. Sexual and asexual structures from selected 3-week-old cultures were mounted in $80 \%$ lactic acid on glass slides and examined using an Axioskop microscope (Carl Zeiss). Fifty measurements were made for each structure for the isolate chosen to represent the holotype and 10 measurements were taken for each structure of two additional isolates treated as paratypes. All measurements were computed and presented as (minimum-) mean minus SD - mean plus SD (-maximum). Colony morphology and colour (upper and reverse surfaces) were determined using the colour charts of Rayner (1970). To determine the optimal temperature for growth, three cultures (CMW 43272, CMW 43273, CMW 43281) were incubated at temperatures ranging from 5 to $35^{\circ} \mathrm{C}$ at five-degree intervals, measurements were taken as described by Liu et al. (2015).

\section{Pathogenicity tests}

\section{Pathogenicity on C. esculenta and E. japonica}

To consider the pathogenicity of the Ceratocystis species from C. esculenta, and thus to fulfil Koch's postulates, inoculations were made on $C$. esculenta corms. In this experiment, four representative Ceratocystis isolates (CMW 43268, CMW 43273, CMW 43280, CMW 43281) obtained from different $C$. esculenta corms were used.

Isolates were grown on $2 \%$ MEA at $25^{\circ} \mathrm{C}$ for 2 weeks. MEA plugs of $5 \mathrm{~mm}$ in diameter, covered with mycelium, were cut from the edges of the actively growing colonies. These plugs were used to inoculate $20 \mathrm{C}$. esculenta corms for each of the four test isolates and an equal number were inoculated with sterile MEA plugs to serve as negative controls. Wounds, approximately $2 \mathrm{~mm}$ deep, were made on the surfaces of the corms using a cork borer ( $5 \mathrm{~mm}$ diameter) and the MEA plugs were transferred, mycelium surface facing downwards, into the holes, which were then sealed with Parafilm. Inoculated corms were placed in sealed plastic boxes, the bases of which were lined with moist paper to retain humidity. These boxes were kept in a growth chamber and subjected to a constant temperature of $25^{\circ} \mathrm{C}$ with natural day/night conditions for a period of 20 days.

The four C. esculenta isolates (CMW 43268, CMW 43273, CMW 43280, CMW 43281) were also inoculated onto the stems of $E$. japonica saplings, because they had ITS sequences identical to the E. japonica isolates considered by Li et al. (2014a). The E. japonica saplings used for inoculations were 1.5 years old, $60-80 \mathrm{~cm}$ in height and had diameters ranging from 1.0 to $1.2 \mathrm{~cm}$. After acclimatization in a shade house for 2 weeks, 20 E. japonica saplings were inoculated with each of the four isolates. Wounds were made approximately $30 \mathrm{~cm}$ above the soil surface using a 5-mm-diameter cork borer to expose the cambium. MEA plugs covered with mycelium were placed into the wounds using the same method 
employed for the $C$. esculenta corms. Twenty additional saplings were inoculated in the same way but with sterile MEA plugs to serve as negative controls.

Results were recorded after 3 weeks for $C$. esculenta and after 4 weeks for the E. japonica trial. This was done by measuring the lesion lengths (including the cork-borer wound) for each treatment. Reisolations were made from these lesions by cutting small pieces of corm/wood from the lesion edges and transferring these to 2\% MEA and incubating the plates at $25^{\circ} \mathrm{C}$. Reisolations were made from four randomly selected corms and eight saplings for each isolate and from all the control inoculations. Results of all trials were analysed in excel (2013) using single factor analysis of variance (ANOVA) to test the effects of Ceratocystis isolate on lesion length. $F$-values with $P<0.05$ were considered significantly different. The standard errors of means of lesion/wound length for each isolate and the controls were calculated.

\section{Comparison of isolate aggressiveness and host susceptibility}

In a second experiment, the host specificity was investigated of the isolates from C. esculenta and its close phylogenetic relative, $C$. cercfabiensis, recently described from Eucalyptus trees in China (Liu et al., 2015). Three isolates from C. esculenta (CMW 43272, CMW 43273, CMW 43281) and three $C$. cercfabiensis isolates (CMW 42515, CMW 42795, CMW 43029) obtained from Eucalyptus species (Liu et al., 2015) were used in a reciprocal inoculation onto both $C$. esculenta corms and $E$. grandis saplings. The six isolates were prepared as described above.

Twenty corms of $C$. esculenta and 20 E. grandis clone (CEPT-10) saplings (1-year-old, approximately $200 \mathrm{~cm}$ high, 1.0-1.2 cm diameter) were inoculated, using the method described above. Twenty additional corms and saplings were inoculated in the same way but with sterile MEA plugs to serve as negative controls.

In the second trial, results were read after 2 weeks for $C$. esculenta and 4 weeks for E. grandis, as described above.

\section{Results}

\section{Fungal isolations}

Abundant ascomata were found on the surfaces of the $C$. esculenta corms exhibiting black rot. In total, 31 isolates were obtained, of which 14 were from six diseased corms collected in the YunNan Province, and 17 were from eight diseased corms from the ShanDong Province. Based on morphological characteristics of the cultures and the ascomata produced on MEA, all the isolates were tentatively identified as species of Ceratocystis. These isolates grew relatively slowly on MEA and had a strong fruity (banana) odour. All isolates had brown to dark, globoid ascomata with long necks, without spines on their bases, and they produced hat-shaped, sheathed ascospores. Both bacilliform and barrelshaped conidia were observed and cultures also produced dark aleurioconidia in chains. 


\section{ITS+BT1+TEF+MS204+RPBII}

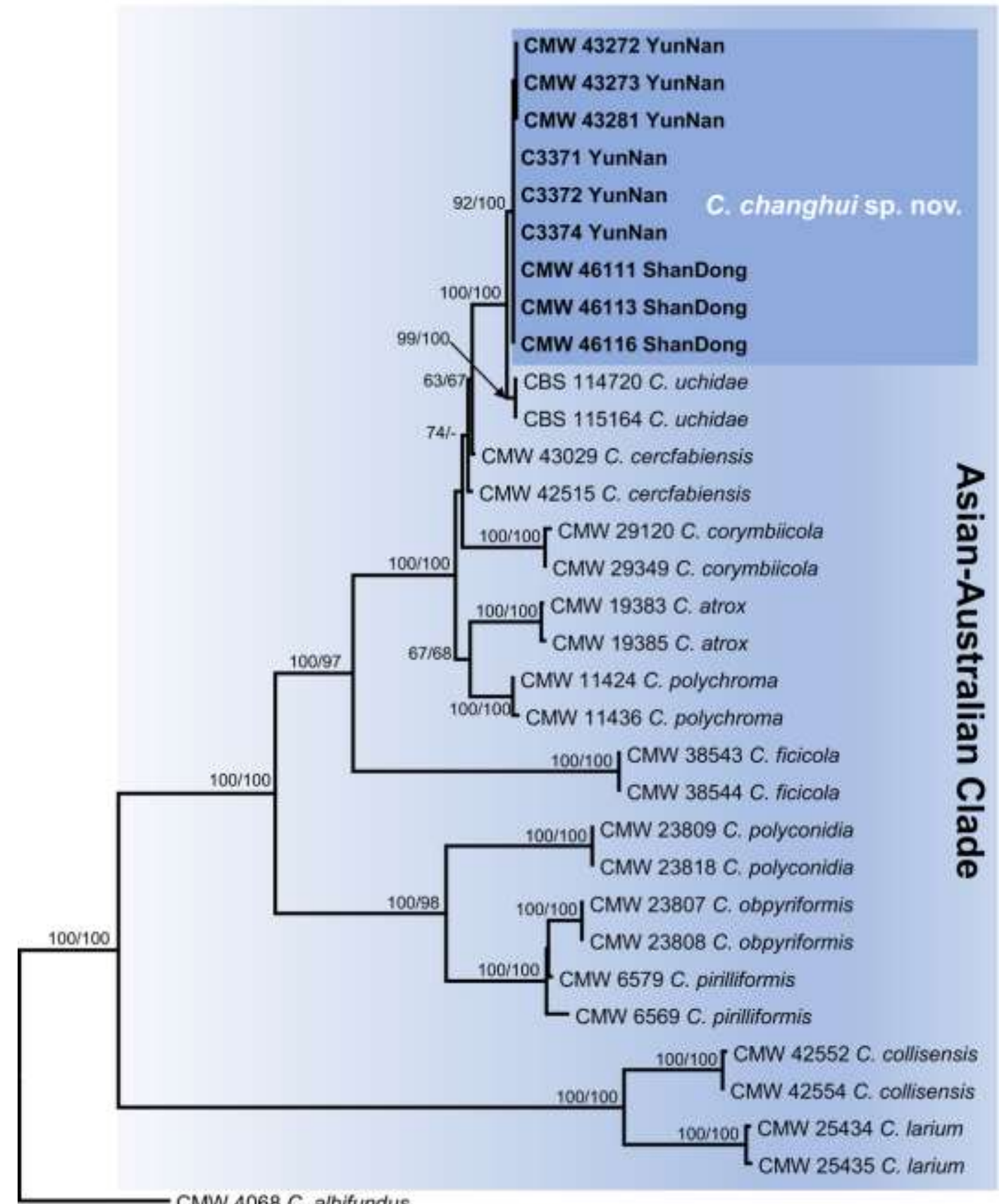

CMW 4068 C, albifundus

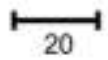

Figure 2. Phylogenetic trees based on maximum parsimony (MP) analysis of a combined dataset of ITS, BT1, TEF-1 $\alpha$, MS204 and RPBII gene sequences for Ceratocystis species in the Asian-Australian clade. Isolates in bold and highlighted are the new species of Ceratocystis changhui described in this study. Bootstrap values $>50 \%$ for MP and maximum likelihood (ML) are presented above branches as MP/ML, bootstrap values absent are not shown or marked with -. Scale bar indicates 20 changes. 


\section{ITS}

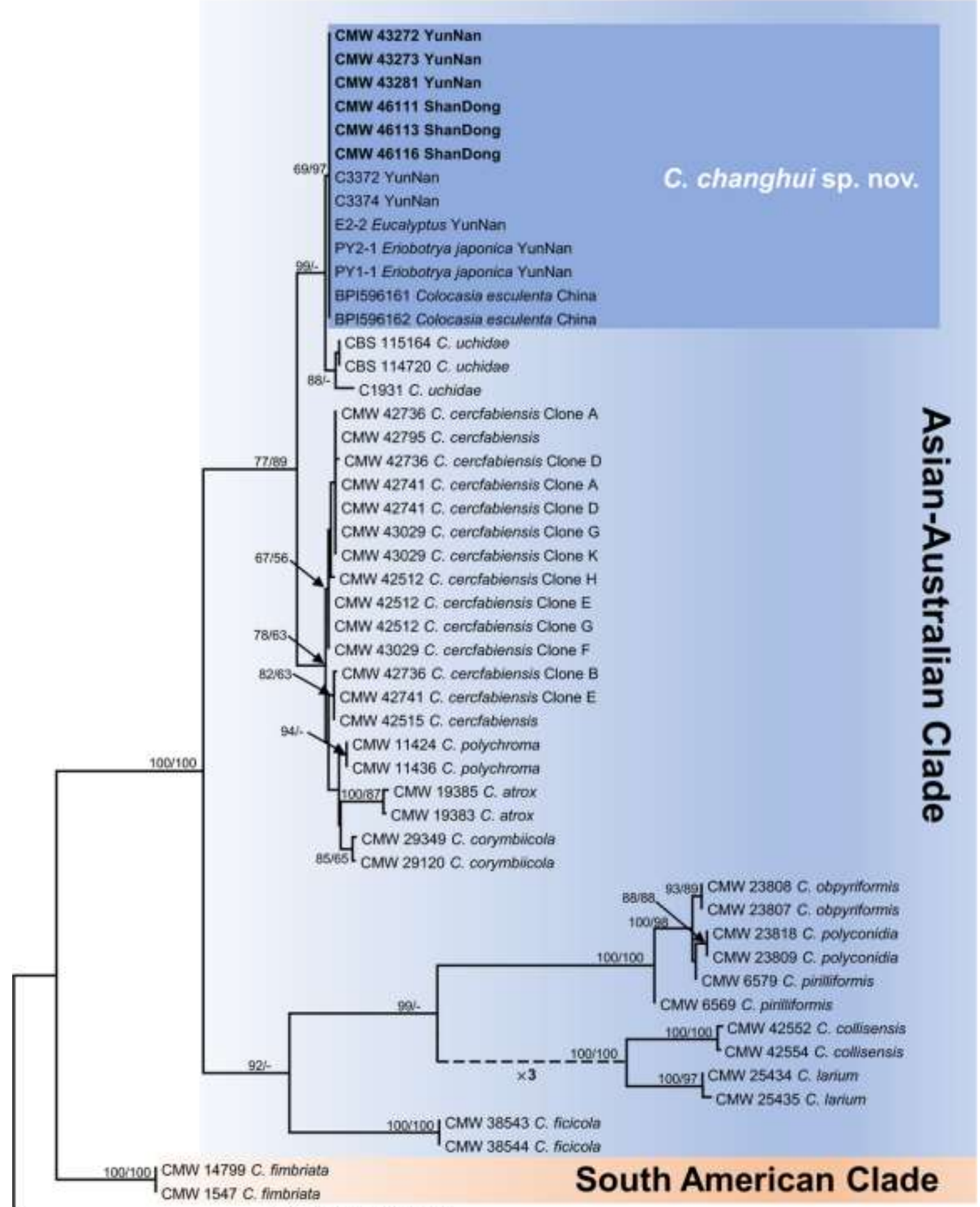

CMW $11164 D$. virescens

Figure 3. Phylogenetic trees based on maximum parsimony (MP) analysis of datasets of ITS sequences for Ceratocystis species in the Asian-Australian clade. Isolates in bold and highlighted are the new species of Ceratocystis changhui described in this study. Bootstrap values $>50 \%$ for MP and maximum likelihood (ML) are presented above branches as MP/ML, bootstrap values absent are not shown or marked with -. The dotted line indicates that the length of the line has been shortened by a multiple of three. Scale bar indicates 10 changes. 


\section{Sequencing and multigene phylogenetic analyses}

Sequencing of the ITS gene region was carried out for preliminary identification of the 31 isolates obtained from $C$. esculenta and the six isolates of Ceratocystis sp. ' $Y$ ' from Eucalyptus obtained from the study by Li et al. (2017). Subsequently, six C. esculenta isolates representing all of the areas sampled and three isolates of Ceratocystis sp. ' $Y$ ' were selected for further phylogenetic analyses (Table 1 ). These isolates were combined into datasets with the ex-type strains of the 11 AAC Ceratocystis species (C. atrox, C. cercfabiensis, C. collisensis, C. corymbiicola, C. ficicola, C. larium, C. obpyriformis, C. piriliformis, C. polychroma, C. polyconidia, C. uchidae; Table 1). PCRs resulted in amplicons of approximately 610, 610, 780, 970 and 1200 bp for the ITS, BT1, TEF-1 $\alpha$, MS204 and RPBII loci, respectively. Partition homogeneity tests (PHT) with 1000 replicates for the five gene regions produced a value of $P=0.001$, indicating some incongruence in the datasets for the five loci. Although the $P$-value was low, sequences of the multiple regions were combined for presentation purposes. The combined phylogeny and individual ITS phylogenies are presented in Figures 2 and 3, respectively. In addition, individual phylogenetic trees are presented in Figures S1, S2, S3 and S4.

All sequences obtained for the Ceratocystis isolates in this study were deposited in GenBank (Table 1), and a summary of the most important parameters applied in the phylogenetic analyses is presented in Table 2. The aligned sequences for the ITS (51 taxa, 711 characters), BT1 (32 taxa, 553 characters), TEF-1a (32 taxa, 768 characters), MS204 (32 taxa, 948 characters), RPBII (32 taxa, 1147 characters), and the combined (32 taxa, 4137 characters) datasets were deposited in TreeBASE (no. 21842).

The MP and ML analyses of the datasets provided trees with generally consistent topologies and phylogenetic relationships among taxa. The 11 Ceratocystis species in the AAC could be distinguished using a combination of five gene regions (Fig. 2). Among the five gene trees, the ITS tree gave the best resolution for separating all the species in the AAC (Fig. 3). However, some closely related species could not be separated by single gene trees (Figs S1, S2, S3 and S4). For example, the MS204 gene tree could not distinguish between C. cercfabiensis and C. uchidae, C. obpyriformis and C. pirilliformis (Fig. S3). Likewise, the $R P B I /$ gene tree could not distinguish between C. obpyriformis and C. pirilliformis (Fig. S4).

Based on the MP and ML phylogenetic analyses, the isolates from C. esculenta in China formed a well-resolved lineage residing in the AAC in the ITS tree (Fig. 3), separated from all previously described Ceratocystis species (phylogenetic bootstrap value of MP/ML: $69 \% / 97 \%)$. This lineage was supported by phylogenies based on the combined five gene trees (phylogenetic bootstrap value of MP/ML: 92\%/100\%, Fig. 2). However, in the separate $B T 1, T E F-1 \alpha, M S 204$ and RPBIl gene trees (Figs S1, S2, S3 and S4), the lineage was not distinct and could not be separated from $C$. uchidae or $C$. cercfabiensis. Similarly, not all gene regions could be used to distinguish all of the species in the AAC. Based on the phylogenetic analyses, the isolates from $C$. esculenta in China were considered as a putative new species.

Based on ITS sequence data, the $C$. esculenta isolates in this study were identical to isolates reported previously from E. japonica (E2-2) and Eucalyptus (PY1-1, PY2-1) by Li et al. 
Table 2 Parameters used in all phylogenetic analyses in this study.

\begin{tabular}{|c|c|c|c|c|c|c|}
\hline & ITS & BT1 & $T E F-1 \alpha$ & MS204 & $R P B / I$ & Combined \\
\hline No. of taxa & 51 & 32 & 32 & 32 & 32 & 32 \\
\hline No. of $b p^{a}$ & 711 & 553 & 768 & 948 & 1147 & 4137 \\
\hline No. of trees & 20 & 2 & 3 & 2 & 12 & 5 \\
\hline Tree length & 604 & 112 & 108 & 152 & 81 & 991 \\
\hline $\mathrm{Cl}^{\mathrm{C}}$ & 0.813 & 0.920 & 0.731 & 0.901 & 0.852 & 0.809 \\
\hline $\mathrm{HI}^{\mathrm{e}}$ & 0.187 & 0.080 & 0.269 & 0.099 & 0.148 & 0.191 \\
\hline Subst. model ${ }^{f}$ & TPM1uf+G & $\mathrm{HKY}+\mathrm{I}$ & $\mathrm{TIM} 2+\mathrm{G}$ & $\mathrm{HKY}+\mathrm{I}$ & TrNef+I & $\mathrm{TIM} 2+\mathrm{I}+\mathrm{G}$ \\
\hline $\mathrm{NST}^{\mathrm{g}}$ & 6 & 2 & 6 & 2 & 6 & 6 \\
\hline P-inv ${ }^{h}$ & - & 0.626 & - & 0.539 & 0.758 & 0.505 \\
\hline Gamma $^{i}$ & 0.339 & - & 0.021 & - & - & 0.514 \\
\hline
\end{tabular}

aBase pairs.

${ }^{\mathrm{b}}$ Number of parsimony informative characters.

${ }^{\mathrm{C}}$ Consistency index.

${ }^{\mathrm{d}}$ Retention index.

eHomoplasy index.

fBest-fit substitution model.

gNumber of substitution rate categories.

${ }^{\text {h}}$ Proportion of invariable sites.

'Distribution shape parameter. 
(2014a,b), where they were referred to as C. fimbriata s.I. (Fig. 3). The ITS sequence was also identical to those from C. esculenta (BPI 596161, BPI 596162) and Eucalyptus (C3371C3376) of the undescribed Ceratocystis sp. ' $Y$ ' (Fig. 3; Li et al., 2017). This suggests that the isolates from $C$. esculenta in the present study are the same as those previously studied (Thorpe et al., 2005; Li et al., 2014a,b, 2017).

\section{Microsatellite amplification and genetic analyses}

\section{Allele scoring and genotyping}

Of the 32 microsatellite markers tested, 23 were successfully amplified for all isolates and shown to be polymorphic for all but two isolates of one species, $C$. corymbiicola, in the AAC. For $C$. corymbiicola, 16 of the 23 markers produced multiple alleles that were difficult to score. As a result, this species was excluded from further analyses (Table S1). Alleles ranged from 2 to 10 at each locus, with a total of 139 alleles obtained from the 23 loci (Table S2). Forty-one unique MLGs were obtained when analysing the 23 polymorphic microsatellite loci across all isolates of the putative new species from $C$. esculenta in China and the other 10 species in the AAC.

Of the 41 different MLGs detected in the 97 isolates (Table S1), 20 were from

C. cercfabiensis ( 40 isolates), 5 from the putative new species ( 37 isolates), 1 from

C. uchidae ( 2 isolates), 1 from C. atrox ( 2 isolates), 2 from C. pirilliformis ( 2 isolates), 2 from

C. obpyriformis ( 2 isolates), 2 from C. larium ( 2 isolates), 2 from C. polychroma ( 2 isolates), 3 from C. collisensis ( 4 isolates), 2 from $C$. polyconidia ( 2 isolates) and 1 from C. ficicola ( 2 isolates) (Fig. 4; Table S1). There were no shared MLGs among the putative new species and 10 other Ceratocystis species.

Of the 139 alleles obtained from the 23 loci, 79 alleles (56.8\% of all 139 alleles) were private alleles (Table S2) and thus unique to a particular species. Among the 79 private alleles, there were 15 alleles (19.0\%) from C. ficicola, 14 alleles (17.7\%) from C. polyconidia, 9 alleles (11.4\%) each from C. collisensis and C. larium, 7 alleles (8.9\%) from C. atrox, 6 alleles (7.6\%) from the new putative species, 5 alleles (6.3\%) each from $C$. cercfabiensis, $C$. uchidae and C. polychroma, and 2 alleles (2.5\%) each from C. pirilliformis and C. obpyriformis (Table S2). The high numbers of private alleles in each species reflected a high level of diversity and variation in Ceratocystis species residing in this clade.

\section{UPGMA analyses}

The genetic distance between isolates of the 10 Ceratocystis species in the AAC and the isolates of the putative new species from the present study (Fig. 4), provided results similar to those obtained from phylogenetic analyses. Here, all the isolates representing different species clustered together in the UPGMA (Fig. 4), providing additional support for species delimitation for the Ceratocystis species residing in the AAC. A total of 41 haplotypes were revealed in the UPGMA data where some species showed some low level of variation within species. A higher level of variation within species was clear, for example, within C. pirilliformis and C. collisensis. Although variation was observed in the isolates of C. cercfabiensis, the $20 \mathrm{MLGs}$ from this species formed an independent clade. Even though 
the $C$. esculenta isolates considered in this study were closely related to $C$. cercfabiensis and C. uchidae, they were clearly separated into a distinct clade in the UPGMA tree (Fig. 4).

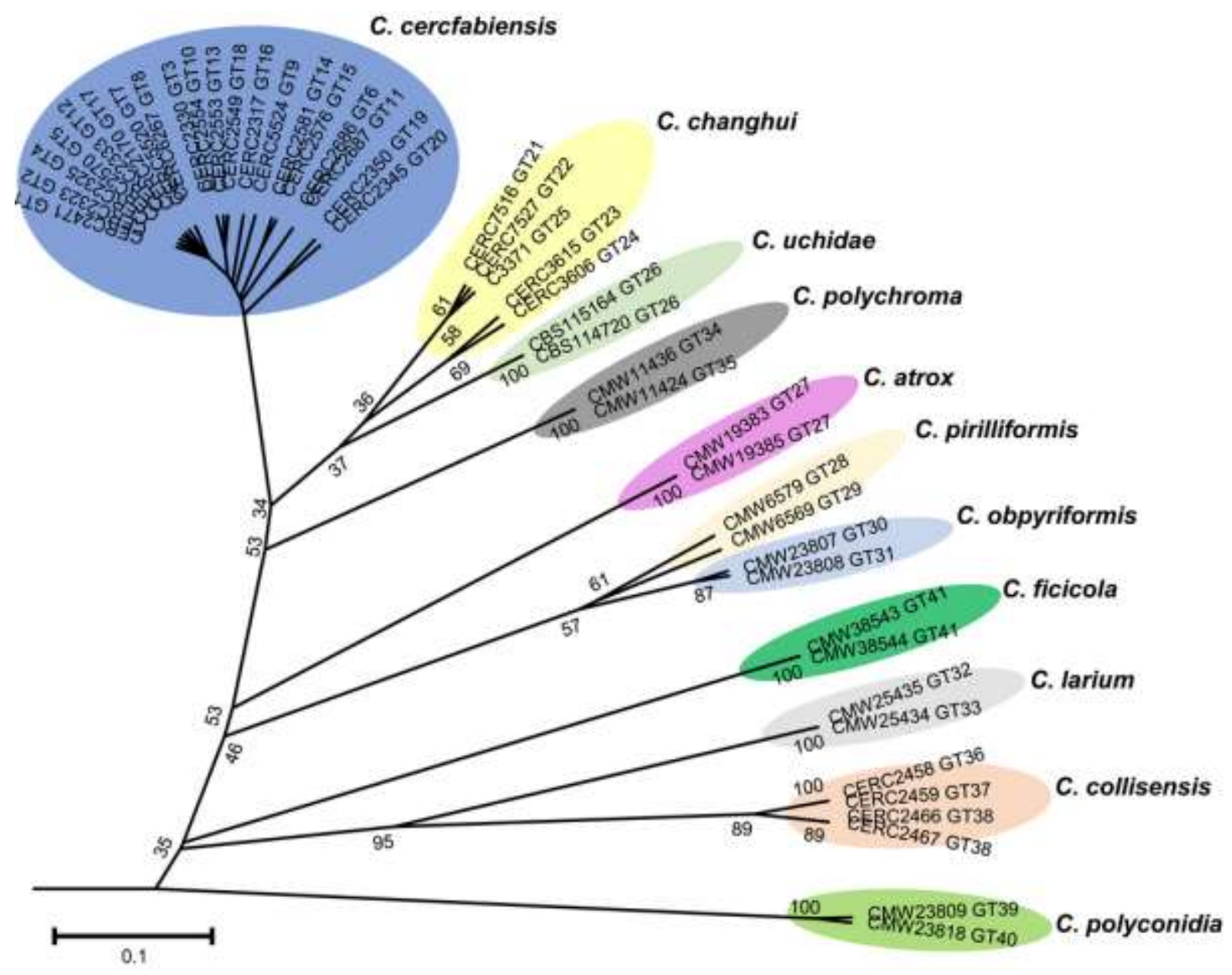

Figure 4. A UPGMA (unweighted pair group method, arithmetic mean) dendrogram of genotypes of Ceratocystis isolates in Asian-Australian clade based on alleles of 23 polymorphic microsatellite loci. Bootstrap values from 1000 replications are shown alongside the branches. Scale bar indicates genetic distance.

\section{Morphological comparisons and taxonomy}

Based on a phylogenetic analysis of five gene regions as well as an analysis of microsatellite data in a UPGMA tree, it was clear that the Ceratocystis species in the AAC could be clearly distinguished from each other. The isolates collected from $C$. esculenta in China that formed the basis of this study represent an undescribed taxon. It was most similar to $C$. uchidae and C. cercfabiensis, but could be distinguished from its closest relatives based on morphological differences including colour of the ascomatal bases, length of ostiolar hyphae, size of ascospores and size of cylindrical conidia (Table 3). A novel taxon is consequently described for these isolates as follows: 
Table 3 Morphological comparison of Ceratocystis changhui with other phylogenetically closely related species.

\begin{tabular}{|c|c|c|c|c|c|c|}
\hline & C. changhui & C. uchidae & C. cercfabiensis & C. corymbiicola & C. polychroma & C. atrox \\
\hline Ascomata base & $\begin{array}{c}(139-) 153.5-209(-261) \times \\
(132.5-) 154-207.5(-257)\end{array}$ & 95-190 diam. & $\begin{array}{c}(100-) 137-218.8(-302) \times \\
(79-) 138-231(-286)\end{array}$ & $\begin{array}{l}(159-) 189-241(-290) \times \\
(160.5-) 185.0-237.5(-272.5)\end{array}$ & (208-)217-261(-269) diam. & (120-)140-180(-222) diam. \\
\hline Ascomata base average & $182.0 \times 180.5$ & 95.0-190.0 diam. & $177.9 \times 184.5$ & $215.0 \times 211.0$ & $239.0 \times 239.0$ & $160.0 \times 160.0$ \\
\hline Ascomata neck & $(453.5-) 594-810(-896.5)$ & $325-520$ & $(473-) 829-1400(-1756)$ & $(603-) 755-1009(-1097.5)$ & $(837-) 849-1071(-1187)$ & $(277-) 313-401(-451)$ \\
\hline Ascomata neck average & 702 & 422.5 & 1114.5 & 882 & 960 & 357 \\
\hline Ostiolar hyphae & $(51-) 58.5-105.5(-173)$ & $40-75$ & $(32-) 48-70(-82)$ & $(22.5-) 42-58.5(-67.5)$ & $(31-) 33-43(-46)$ & $(18-) 20-26(-28)$ \\
\hline Ostiolar hyphae average & 82 & 57.5 & 59 & 50.3 & 38 & 23 \\
\hline Ascospores & $\begin{array}{c}(4.5-) 5.0-6.0(-6.5) \times \\
(2.5-) 3.0-3.5(-4.0)\end{array}$ & $4.0-6.0 \times 2.0-3.5$ & $\begin{array}{c}(4.1-) 5.7-6.8(-7.5) \times \\
(2.5-) 3.1-3.9(-4.6)\end{array}$ & $\begin{array}{c}(4.5-) 5.0-5.5(-6.0) \times \\
(2.5-) 3.0-3.5(-4.0)\end{array}$ & $5-7 \times 3-4$ & $4-6 \times 3-4$ \\
\hline Ascospores average & $5.5 \times 3.5$ & $5.0 \times 2.75$ & $6.3 \times 3.5$ & $5.3 \times 3.3$ & $6.0 \times 3.5$ & $5.0 \times 3.5$ \\
\hline Cylindrical conidia & $\begin{array}{c}(6.5-) 10.5-16.5(-22.5) \times \\
(3.5-) 4.5-5.5(-6.5)\end{array}$ & $10-25 \times 2-4$ & $\begin{array}{c}(8.8-) 16.2-25.6(-49.9) \times \\
(2.7-) 3.4-4.6(-2.7)\end{array}$ & $\begin{array}{l}(11.0-) 15.0-21.5(-27.5) \times \\
(3.0-) 3.5-4.5(-5.5)\end{array}$ & $(13-) 16-24(-26) \times 3-5$ & $(9-) 11-15(-17) \times 3-5$ \\
\hline Cylindrical conidia average & $13.5 \times 5.0$ & $17.5 \times 3.0$ & $20.9 \times 4.0$ & $18.3 \times 4.0$ & $20.0 \times 4.0$ & $13.0 \times 4.0$ \\
\hline Barrel-shaped conidia & $\begin{array}{c}(3.5-) 5.5-9.0(-10.5) \times \\
(3.5-) 4.0-5.5(-6.0)\end{array}$ & Not present & Not present & $\begin{array}{l}(7.5-) 8.5-12.0(-14.5) \times \\
(3.5-) 4.0-5.5(-6.5)\end{array}$ & $9-11 \times 6-8$ & $\begin{array}{l}(7-) 8-12(-14) \times \\
(5-) 6-8(-9)\end{array}$ \\
\hline Barrel-shaped conidia average & $7.0 \times 4.5$ & & & $10.3 \times 4.8$ & $10.0 \times 7.0$ & $10.0 \times 7.0$ \\
\hline Aleurioconidia & $\begin{array}{c}(8.5-) 10.0-12.5(-14.0) \times \\
(6.0-) 8.0-10.0(-11.5)\end{array}$ & $7.5-12.5 \times 7.0-9.5$ & $\begin{array}{c}(9.9-) 12.1-15.0(-16.7) \times \\
(7.0-) 9.2-11.5(-13.0)\end{array}$ & $\begin{array}{c}(8.5-) 11.0-12.0(-16.5) \times \\
(6.5-) 8.0-11.0(-16.5)\end{array}$ & $11-14 \times 8-14$ & Not present \\
\hline Aleurioconidia average & $11.5 \times 9.0$ & $10.0 \times 8.3$ & $13.6 \times 10.4$ & $11.5 \times 9.5$ & $12.5 \times 11.0$ & \\
\hline Ascomata base colour & Brown, occasionally black & Black & Dark brown to black & Black & Dark brown to black & Dark brown to black \\
\hline
\end{tabular}

All measurements are in micrometres. 

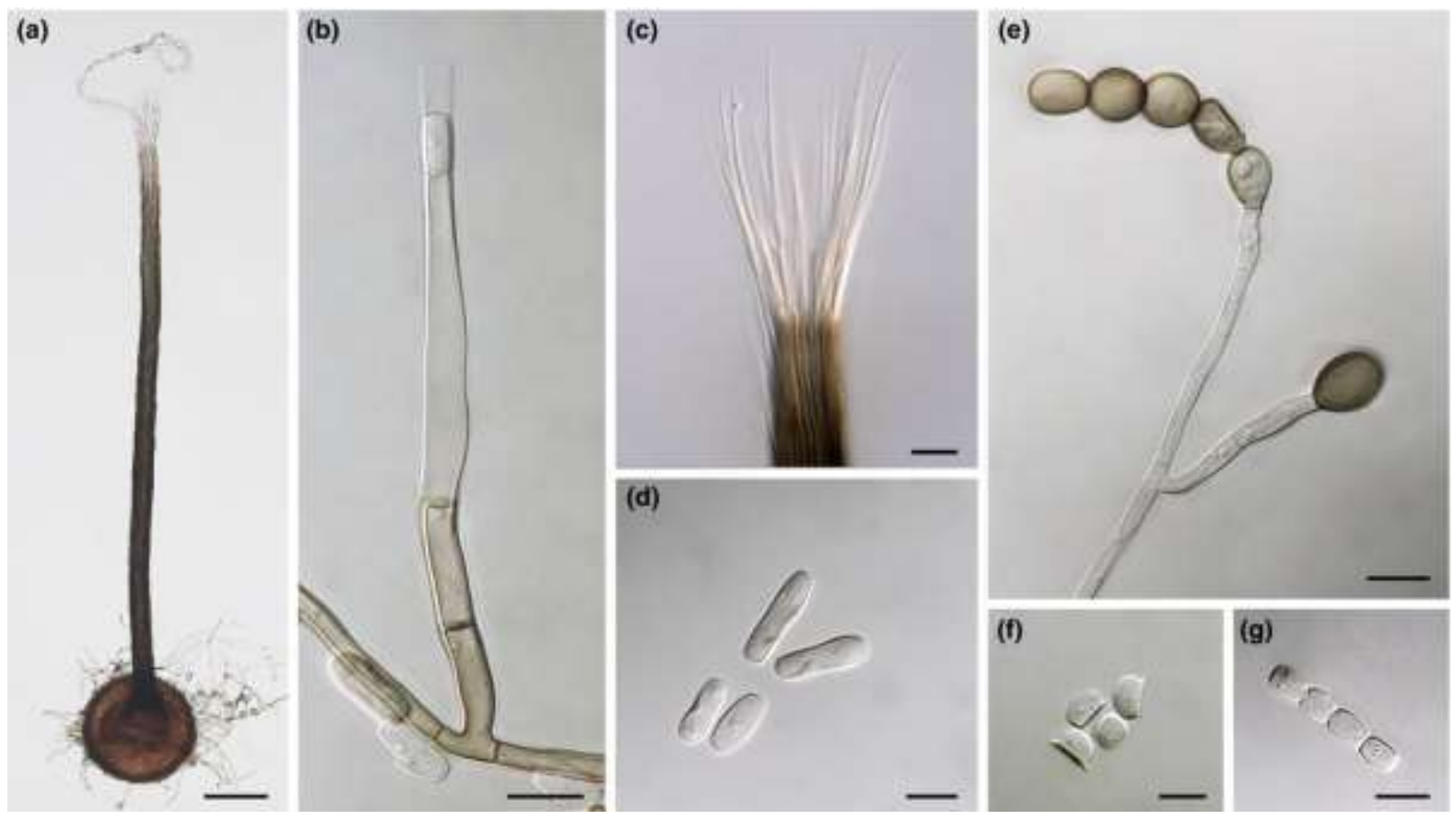

Figure 5. Morphological characteristics of Ceratocystis changhui sp. nov.: (a) ascomata with brown, globose to obpyriform base; (b) flask-shaped conidiophore; (c) divergent ostiolar hyphae; (d) various sizes of bacilliform conidia; (e) aleurioconidia in chains and solitary; ( $f$ ) hat-shaped ascospores in side view and top view; (g) barrel-shaped conidia in a chain. Scale bars: $a=100 \mu \mathrm{m} ; b, d, e, g=10 \mu \mathrm{m} ; f=5 \mu \mathrm{m} ; c=20 \mu \mathrm{m}$.

\section{MycoBank MB815611}

Etymology: the name is derived from the Chinese word for Ceratocystis ('Changhui').

Culture characteristics: Colonies on MEA olivaceous (21"k), reverse olivaceous (21"k). Mycelium immersed and superficial. Hyphae smooth, septate, without constriction at septa. Colony surfaces with scattered dark brown to black ascomata. Slow-growing, optimal temperature for growth $25^{\circ} \mathrm{C}$, no growth at 5,10 or $35^{\circ} \mathrm{C}$. After 14 days, colonies at 15,20 , 25 and $30^{\circ} \mathrm{C}$ reached $30.1,38.8,58.3$ and $33.6 \mathrm{~mm}$, respectively.

Sexual state: Ascomatal bases brown, occasionally black, globose to oval, semi-transparent, (139-)153.5-209(-261) $\mu \mathrm{m}$ long and (132.5-)154-207.5(-257) $\mu \mathrm{m}$ wide in diameter. Spines or ornamentations absent. Ascomatal necks dark brown to black, erect, slender, (453.5)594-810(-896.5) $\mu \mathrm{m}$ long, (19.5-)24.5-35.5(-47) $\mu \mathrm{m}$ wide at apices and (28.5-)37-52.5(63.5) $\mu \mathrm{m}$ wide at bases. Ostiolar hyphae present, hyaline, divergent, (51-)58.5-105.5(-173) $\mu \mathrm{m}$ long. Asci not observed. Ascospores hat-shaped, invested in sheaths, aseptate, (4.5-)5$6(-6.5) \mu \mathrm{m}$ long and (2.5-)3-3.5(-4) $\mu \mathrm{m}$ wide with sheaths in side view. Ascospores accumulating in buff yellow (19 d) mucilaginous masses at the tips of ascomatal necks.

Asexual state: phialidic, with enteroblastic conidium ontogeny. Conidiophores flask-shaped producing bacilliform conidia, hyaline at apices, turning brown towards bases, multiseptate, lageniform, tubular, variable in size when terminal on hyphae, tapering at apices, (43.5-)6095(-122) $\mu \mathrm{m}$ long, (3-)3.5-4.5(-6) $\mu \mathrm{m}$ wide at apices and (3.5-)4.5-6(-7.5) $\mu \mathrm{m}$ wide at 
bases. Bacilliform conidia hyaline, aseptate, cylindrical, (6.5-)10.5-16.5(-22.5) $\mu \mathrm{m}$ long and (3.5-)4.5-5.5(-6.5) $\mu \mathrm{m}$ wide. Barrel-shaped conidia hyaline, aseptate, in chains, (3.5-)5.59(-10.5) $\mu \mathrm{m}$ long and (3.5-)4-5.5(-6) $\mu \mathrm{m}$ wide. Aleurioconidia ovoid, smooth, dark brown, embedded in agar, produced in chains or single, $(8.5-) 10-12.5(-14) \times(6-) 8-10(-11.5) \mu \mathrm{m}$ in size.

Substrate: Black rot of Colocasia esculenta (taro) in China.

Distribution: YunNan and ShanDong Provinces, China.

Specimen examined: China, YunNan Province, KunMing Region, ChangShui Town, farm market. Isolated from lesions of black rot on Colocasia esculenta, August 2014, S.F. Chen. Dried specimens were deposited with the National Collection of Fungi (PREM), Pretoria, South Africa. HOLOTYPE PREM 61241, culture ex-type CMW 43281 = CERC $3615=$ CBS 139797. GenBank accession numbers are KY643884, KY643919, KY643941, KY643962 and KY644015 for ITS, BT1, TEF, MS204 and RPBII gene regions, respectively.

Additional specimens: China, YunNan Province, KunMing Region, ChangShui Town, farm market isolated from lesions of black rot on Colocasia esculenta, August 2014, S.F. Chen. Dried specimens were deposited with PREM. PARATYPE PREM 61242, culture CMW 43272 = CERC 3605 = CBS 139798. GenBank accession numbers are KY643886, KY643915, KY643937, KY643958 and KY644011 for ITS, BT1, TEF, MS204 and RPBII gene regions, respectively. PARATYPE PREM 61243, culture CMW $43273=$ CERC $3606=$ CBS 139799. GenBank accession numbers are KY643889, KY643916, KY643938, KY643959 and KY644012 for ITS, BT1, TEF, MS204 and RPBII gene regions, respectively.

Notes. Ceratocystis changhui is phylogenetically most closely related to C. uchidae (Li et al., 2017) and C. cercfabiensis (Liu et al., 2015), but can be distinguished from these two species by the colour of the ascomatal bases and the lengths of their necks, ostiolar hyphae and conidia (Table 3). When grown on $2 \%$ MEA at $25^{\circ} \mathrm{C}$, the ascomatal bases of $C$. changhui are brown and semitransparent in contrast to those of $C$. uchidae and $C$. cercfabiensis that are mostly black. Ascomatal necks of $C$. changhui (average $702 \mu \mathrm{m}$ ) are longer than those of C. uchidae (average $422.5 \mu \mathrm{m}$ ) and shorter than those of $C$. cercfabiensis (average $1115 \mu \mathrm{m}$ ). Ostiolar hyphae of $C$. changhui (average $82 \mu \mathrm{m}$ ) are longer than those of $C$. uchidae (average $57.5 \mu \mathrm{m}$ ) and $C$. cercfabiensis (average $59.0 \mu \mathrm{m}$ ). Bacilliform conidia of $C$. changhui (average $13.5 \times 5.0 \mu \mathrm{m}$ ) are shorter than those of $C$. uchidae (average $17.5 \times 3.0 \mu \mathrm{m}$ ) and C. cercfabiensis (average $20.9 \times 4.0 \mu \mathrm{m}$ ). Barrel-shaped conidia are present in C. changhui, but absent in $C$. uchidae and $C$. cercfabiensis. Based on DNA sequence data, $C$. changhui differed from $C$. uchidae at five fixed nucleotide bases in the ITS, 1 bp in the TEF gene and $1 \mathrm{bp}$ in the RPBIl gene regions. There were 16 fixed nucleotide differences between $C$. changhui and $C$. cercfabiensis in ITS region and two in the BT1 gene region. 


\section{Pathogenicity tests}

Pathogenicity on C. esculenta and E. japonica

After 3 weeks, all four C. changhui isolates (CMW 43268, CMW 43273, CMW 43280, CMW 43281) caused black rot (lesions) on C. esculenta corms, and ascomata of a Ceratocystis were abundant on the rotten surfaces of the corms. Lesions did not form on the corms serving as negative controls (Fig. S5). The mean comparison tests showed that the lesions caused by the four $C$. changhui isolates were all significantly larger $(P<0.05)$ than the wounds associated with the controls (Fig. 6).

Only small lesions were produced on the stems of the E. japonica saplings inoculated with the four C. changhui isolates (CMW 43268, CMW 43273, CMW 43280, CMW 43281). The mean comparison tests showed that the lesions produced by isolates CMW 43268 and CMW 43281 were significantly longer than the wounds associated with controls, while the average lesion lengths associated with isolates CMW 43273 and CMW 43280 were not significantly different from the wound tissue found on the controls (Fig. 6).

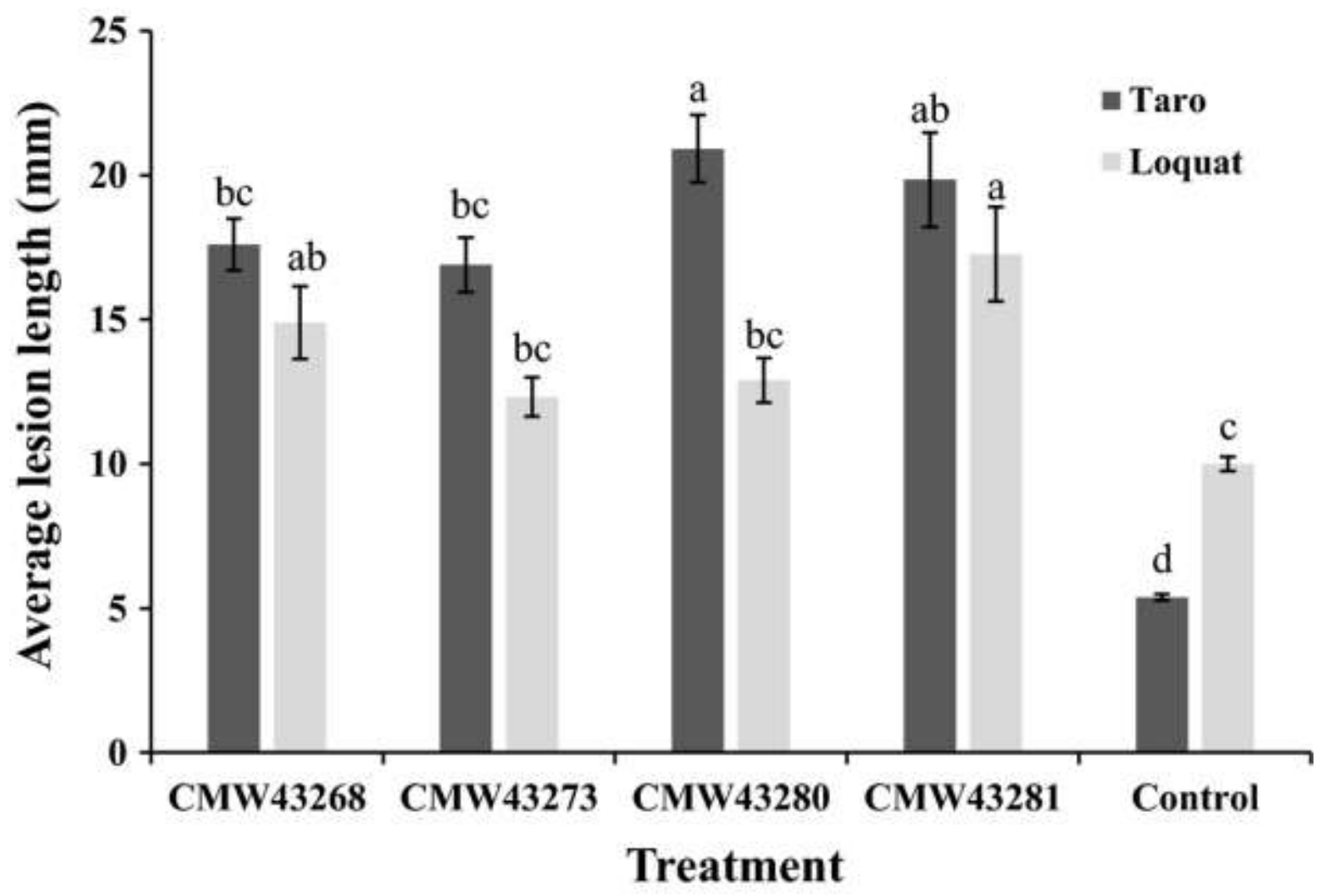

Figure 6. Bar graph showing the average lesion length $(\mathrm{mm})$ resulting from inoculation trials with Ceratocystis changhui on corms of Colocasia esculenta (taro) and Eriobotrya japonica (loquat) saplings. Vertical bars represent standard error of means. Different letters above the bars indicate treatments that were significantly different $(P=0.05)$. 


\section{Comparison of isolate aggressiveness and host susceptibility}

All three $C$. changhui isolates (CMW 43272, CMW 43273, CMW 43281) inoculated on C. esculenta corms caused black rot within 2 weeks. In contrast, only small lesions were produced by C. cercfabiensis (CMW 43029, CMW 42515, CMW 42795), and no rot was observed associated with the control inoculations. The mean comparison tests showed that the lesions caused by the $C$. changhui isolates were all significantly longer $(P<0.05)$ than those caused by $C$. cercfabiensis and the controls (Fig. 7). For the Eucalyptus inoculations, the three $C$. cercfabiensis isolates produced significantly longer lesions than those of the three $C$. changhui isolates $(P<0.05)$, while only small wound-associated discolouration was produced in the control inoculations (Fig. 7). The inoculated Ceratocystis spp. were reisolated from the lesions, but not from the controls.

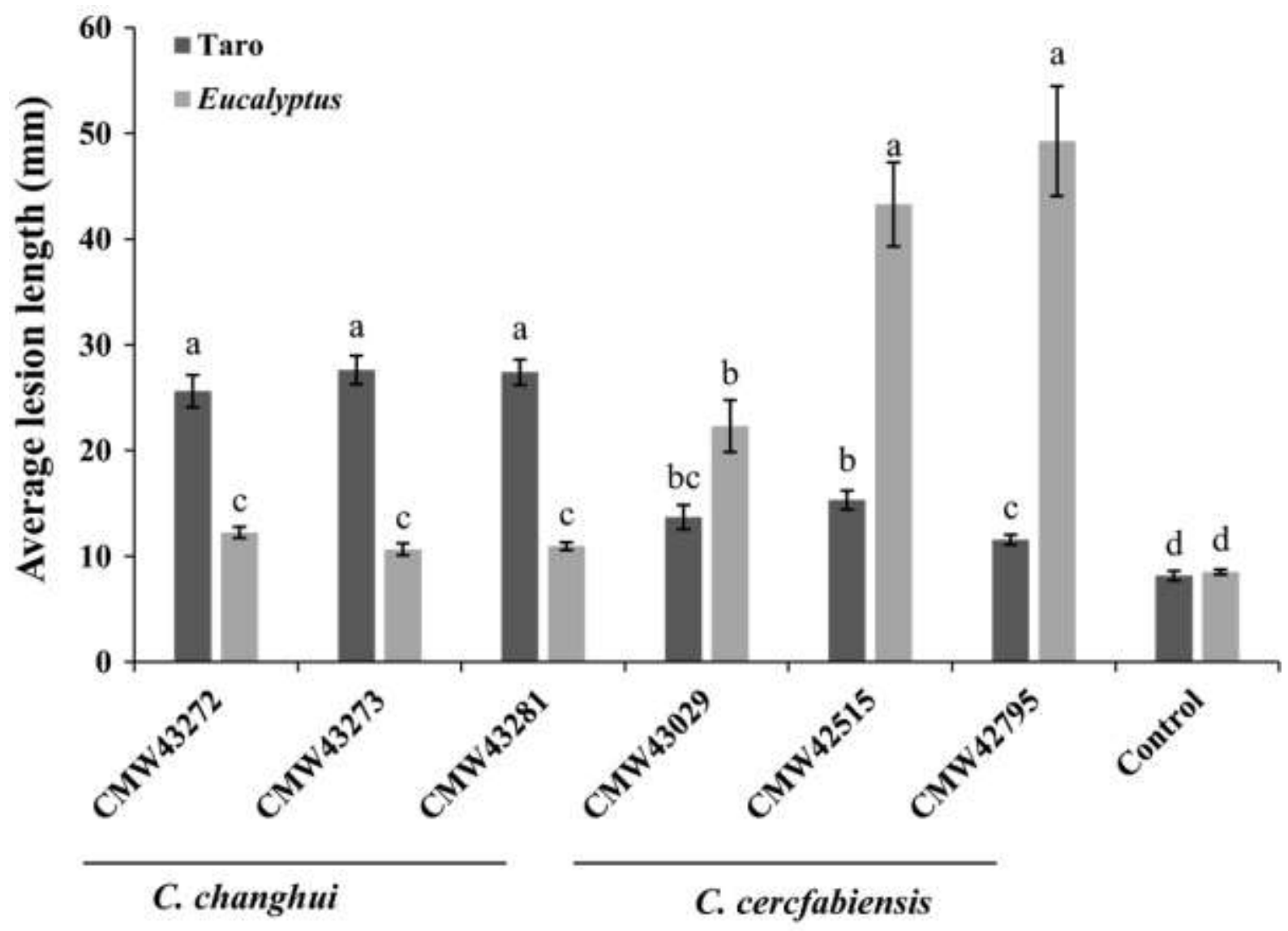

\section{Treatment}

Figure 7. Bar graph showing the average lesion length $(\mathrm{mm})$ resulting from inoculation trials with Ceratocystis changhui and C. cercfabiensis on corms of Colocasia esculenta (taro) and Eucalyptus saplings. Vertical bars represent standard error of means. Different letters above the bars indicate treatments that were significantly different $(P=0.05)$.

\section{Discussion}

This study led to the discovery of a new species of Ceratocystis that causes black rot symptoms on the corms of $C$. esculenta in the YunNan and ShanDong Provinces of China. This species, provided with the name Ceratocystis changhui, resides in the AAC of 
Ceratocystis. The identity of $C$. changhui emerged from phylogenetic analyses for the ITS, $B T 1, T E F-1 \alpha, M S 204$ and $R P B / l$ regions including a comparison with 11 previously described Ceratocystis species in the AAC. Ceratocystis changhui could also be distinguished from its closest relatives based on morphological characteristics. Furthermore, a UPGMA tree derived from microsatellite data provided additional support for the new species, where isolates clustered separately from 11 other species in the AAC. Pathogenicity tests showed that $C$. changhui can cause black rot disease on $C$. esculenta corms, but produced only small lesions on E. grandis and E. japonica.

Sequence comparisons for the ITS region showed that isolates of $C$. changhui described from $C$. esculenta in this study are identical to those of isolates obtained from $E$. japonica and Eucalyptus species by Li et al. (2014a,b). Based on phylogenetic analyses, the isolates previously reported by these authors and treated as $C$. fimbriata s.I. (LAC) more appropriately reside in the AAC. This is in contrast to $C$. fimbriata s.s. known to reside in the LAC (De Beer et al., 2014; Mbenoun et al., 2014; Fourie et al., 2015). Consequently, based on identical ITS sequences (100\%), it is highly likely that the isolates from E. japonica and Eucalyptus sp. reported by Li et al. (2014a,b) also represent C. changhui, described here. However, this view should be tested with sequences for additional gene regions, which was not possible in the present study because appropriate isolates were not available. The ITS sequence of $C$. changhui was also identical to Ceratocystis sp. ' $Y$ ' reported by Li et al. (2017), including two isolates from C. esculenta imported to the USA from China in 1949 (Thorpe et al., 2005; Li et al., 2017) and six isolates from Eucalyptus species. The six Eucalyptus isolates were obtained and sequenced in the present study and, based on phylogenetic analyses for five gene regions, these isolates of Ceratocystis sp. ' $Y$ ' represent $C$. changhui.

Phylogenetic analyses of multiple gene regions are essential when seeking to identify species in Ceratocystis (De Beer et al., 2014; Fourie et al., 2015). The five gene regions selected for this purpose emerged from the study of Fourie et al. (2015), which showed that these genes can be collectively used to accurately delineate species in the AAC of Ceratocystis. Currently, 12 species of Ceratocystis are known in the AAC. Among the five gene regions, ITS was the most variable and informative region, clearly distinguishing between all of these species. The BT1 and TEF-1 $\alpha$ gene regions were also useful but with fewer variable sites. BT1 could not distinguish between $C$. changhui and $C$. uchidae, and TEF$1 \alpha$ could not distinguish between $C$. changhui and C. cercfabiensis. MS204 had the lowest number of variable sites and although seven species could be distinguished from each other, it was not possible to distinguish between $C$. changhui, $C$. uchidae and $C$. cercfabiensis with this marker. RPBIl could not distinguish between $C$. changhui and $C$. cercfabiensis. Ceratocystis obpyriformis and $C$. pirilliformis could not be separated from each other using MS204 or RPBII. Nevertheless, $C$. changhui could be clearly distinguished from its closest relatives when using a combination of sequences for the five gene regions.

UPGMA analyses of MLGs based on microsatellite markers gave additional support to distinguish $C$. changhui from all other species in the AAC. All isolates analysed in this study clustered in 11 different clades that represented the 11 described Ceratocystis species accommodated in the AAC. Within the clusters representing species, a high level of variation between isolates was observed. In addition, based on genetic distance, there was a close relationship between $C$. changhui, $C$. cercfabiensis and $C$. uchidae, which was similar to that 
emerging from the phylogenetic analyses. Results also identified five different MLGs amongst the $C$. changhui isolates, which indicated that this species is not clonal in China. Results presented by Li et al. (2017) suggested that $C$. cercfabiensis could be an interspecific hybrid and that $C$. uchidae might be one of the hybrid parents, although data were not presented to support this view. UPGMA analyses in the present study showed high genetic diversity of $C$. cercfabiensis; the 20 MLGs of this species grouped in an independent clade and did not merge with other species in the AAC. These analyses, based on microsatellite markers, provide no evidence of hybrids between species and this avenue of research should clearly be pursued.

Ceratocystis changhui is closely related to C. uchidae, which was described from Hawaii and Fiji by Li et al. (2017). In the ITS sequences, C. changhui differed by five and 11 bp from C. uchidae isolates CBS 114720/CBS 115164 (Hawaii) and C1931 (Fiji), respectively (Li et al., 2017). Li et al. (2017) conducted interfertility tests between C. uchidae and their species ' $Y$ ', and showed that they were not interfertile. Because the present study has shown that species ' $Y$ ' is the same as $C$. changhui, this provides additional evidence, based on the biological species concept, for the unique nature of $C$. changhui. Furthermore, $C$. changhui can be distinguished from $C$. uchidae based on morphological differences, including the fact that the ascomatal bases of $C$. changhui are brown and semitransparent while those of C. uchidae are mostly black. Ascomata in C. changhui also have longer ascomatal necks and ostiolar hyphae, as well as shorter bacilliform conidia than those of $C$. uchidae.

Ceratocystis changhui can be distinguished from $C$. cercfabiensis based on various morphological characteristics. These include the colour of the ascomatal bases as well as the sizes of their ostiolar hyphae and conidia. These two species could also have been distinguished by their ascomatal neck lengths, according to the original description of C. cercfabiensis; however, the study of Li et al. (2017) expanded the neck length range for C. cercfabiensis, which now overlaps with those for $C$. changhui.

Ceratocystis changhui is an aggressive pathogen causing typical black rot symptoms on corms of $C$. esculenta. Inoculation tests also showed that isolates of this species are able to cause only small lesions or wound-associated discolouration on E. japonica and E. grandis stems. This is in contrast to the closely related $C$. cercfabiensis that is more pathogenic to $E$. grandis, but does not cause serious rot on $C$. esculenta corms. The results of the present study are somewhat in contrast to those of Li et al. (2014a,b); however, those authors used different techniques, making reasonable comparisons difficult. In the present investigation, tree stems of $E$. grandis and $E$. japonica were inoculated and $C$. changhui was shown to be non-pathogenic. Nevertheless, results of pathogenicity tests suggested host preferences for C. changhui and C. cercfabiensis and this is similar to those found for various other Ceratocystis species (Baker et al., 2003; Marin et al., 2003; Oliveira et al., 2015b).

Two species of Ceratocystis are now known from tuber crops in China. In the present study, C. changhui in the AAC was isolated from C. esculenta in two provinces more than $2000 \mathrm{~km}$ from each other. Ceratocystis fimbriata s.s. in the LAC was reported from I. batatas in northern China (Sy, 1956). Tuber crops, especially C. esculenta and I. batatas, are widely planted in China and studies aimed at extending knowledge of the genetic diversity and biology of Ceratocystis species on these plants would be valuable. They would also support 
integrated strategies for the management of Ceratocystis diseases of tuber crops in China and other regions of the world.

\section{Acknowledgements}

The authors are grateful to the National Natural Science Foundation of China (NSFC; project numbers: 31622019 and 31400546), the International Science \& Technology Cooperation Program of China (project number: 2012DFG31830), the Tree Protection and Cooperation Programme (TPCP) and the National Research Foundation (NRF), South Africa, for financial support. They also acknowledge Professor T. C. Harrington, Department of Plant Pathology and Microbiology, lowa State University, who supplied the six cultures of Ceratocystis sp. ' $Y$ '.

\section{References}

Al Adawi AO, Barnes I, Khan IA et al., 2013. Ceratocystis manginecans associated with a serious wilt disease of two native legume trees in Oman and Pakistan. Australasian Plant Pathology 42, 179-93.

Baker CJ, Harrington TC, Krauss U, Alfenas AC, 2003. Genetic variability and host specialization in the Latin American Clade of Ceratocystis fimbriata. Phytopathology 93, 1274-84.

Barnes I, Gaur A, Burgess T, Roux J, Wingfield BD, Wingfield MJ, 2001. Microsatellite markers reflect intraspecific relationships between isolates of the vascular wilt pathogen Ceratocystis fimbriata. Molecular Plant Pathology 2, 319-25.

Chair H, Traore RE, Duval MF et al., 2016. Genetic diversification and dispersal of taro (Colocasia esculenta (L.) Schott). PLoS ONE 11, e0157712.

Chen SF, van Wyk M, Roux J, Wingfield MJ, Xie YJ, Zhou XD, 2013. Taxonomy and pathogenicity of Ceratocystis species on Eucalyptus trees in South China, including C. chinaeucensis sp. nov. Fungal Diversity 58, 267-79.

De Beer ZW, Duong TA, Barnes I, Wingfield BD, Wingfield MJ, 2014. Redefining Ceratocystis and allied genera. Studies in Mycology 79, 187-219.

De Beer ZW, Marincowitz S, Duong TA, Wingfield MJ, 2017. Bretziella, a new genus to accommodate the oak wilt fungus, Ceratocystis fagacearum (Microascales, Ascomycota). MycoKeys 27, 1-19.

Duong TA, De Beer ZW, Wingfield BD, Wingfield MJ, 2012. Phylogeny and taxonomy of species in the Grosmannia serpens complex. Mycologia 104, 715-32.

Engelbrecht CJB, Harrington TC, 2005. Intersterility, morphology, and taxonomy of Ceratocystis fimbriata on sweet potato, cacao and sycamore. Mycologia 97, 57-69.

Farris JS, Kallersjo M, Kluge AG, Bult C, 1995. Testing significance of incongruence. Cladistics 10, 3159.

Fourie A, Wingfield MJ, Wingfield BD, Barnes I, 2015. Molecular markers delimit cryptic species in Ceratocystis sensu stricto. Mycological Progress 14, 1-18. 
Fourie A, Wingfield MJ, Wingfield BD, Thu PQ, Barnes I, 2016. A possible centre of diversity in South East Asia for the tree pathogen, Ceratocystis manginecans. Infection, Genetics and Evolution 41, 7383.

Glass NL, Donaldson GC, 1995. Development of primer sets designed for use with the PCR to amplify conserved genes from filamentous Ascomycetes. Applied and Environmental Microbiology 61, 132330 .

Guindon S, Gascuel O, 2003. A simple, fast, and accurate algorithm to estimate large phylogenies by maximum likelihood. Systematic Biology 52, 696-704.

Halsted BD, 1890. Some fungous disease of sweet potato. Agricultural College Experiment Station Bulletin 76, 1-32.

Harrington TC, 2000. Host specialization and speciation in the American wilt pathogen Ceratocystis fimbriata. Fitopatologia Brasileira 25S, 262-3.

Harrington TC, Thorpe DJ, Marinho VLA, Furtado EL, 2005. First report of black rot of Colocasia esculenta caused by Ceratocystis fimbriata in Brazil. Fitopatologia Brasileira 30, 88-9.

Harrington TC, Kazmi MR, Al Sadi AM, Ismail SI, 2014. Intraspecific and intragenomic variability of ITS rDNA sequences reveals taxonomic problems in Ceratocystis fimbriata sensu stricto. Mycologia 106, 224-42.

Harrington TC, Huang Q, Ferreira MA, Alfenas AC, 2015. Genetic analyses trace the Yunnan, China population of Ceratocystis fimbriata on pomegranate and taro to populations on Eucalyptus in Brazil. Plant Disease 99, 106-11.

Huang Q, Zhu YY, Chen HR et al., 2003. First report of pomegranate wilt caused by Ceratocystis fimbriata in Yunnan, China. Plant Disease 87, 1150.

Huang Q, Wang YY, Zhao YY et al., 2008. First report of taro black rot caused by Ceratocystis fimbriata in China. Plant Pathology 57, 780.

Huelsenbeck JP, Bull JJ, Cunningham CW, 1996. Combining data in phylogenetic analysis. Trends in Ecology \& Evolution 11, 152-8.

Jacobs K, Bergdahl DR, Wingfield MJ et al., 2004. Leptographium wingfieldii introduced into North America and found associated with exotic Tomicus piniperda and native bark beetles. Mycological Research 108, 411-8.

Katoh K, Misawa K, Kuma K, Miyata T, 2002. mafft: a novel method for rapid multiple sequence alignment based on fast Fourier transform. Nucleic Acids Research 30, 3059-66.

Kile GA, 1993. Plant diseases caused by species of Ceratocystis sensu stricto and Chalara. In: Wingfield MJ, Seifert KA, Webber JFF, eds. Ceratocystis and Ophiostoma: Taxonomy, Ecology and Pathogenicity. St Paul, MN, USA: American Phytopathological Society Press, 73-183.

Langella O, 1999. populations 1.2.30. [http://www.bioinformatics.org/populations]. Accessed 2 October 2015. 
Li J, Gao JM, Han YH, Sun YX, Huang Q, 2014a. First report of Ceratocystis fimbriata-caused wilt of Eriobotrya japonica in China. Plant Disease 98, 1270.

J, Zhang Y, Xu KC et al., 2014b. First report of wilt of Eucalyptus caused by Ceratocystis fimbriata in China. Plant Disease 98, 1744.

Li Q, Harrington TC, McNew D et al., 2016. Genetic bottlenecks for two populations of Ceratocystis fimbriata on sweet potato and pomegranate in China. Plant Disease 100, 2266-74.

Li Q, Harrington TC, McNew D, Li J, 2017. Ceratocystis uchidae sp. nov., a new species on Araceae in Hawaii and Fiji. Mycoscience 58, 398-412.

Liu FF, Mbenoun M, Barnes I et al., 2015. New Ceratocystis species from Eucalyptus and Cunninghamia in South China. Antonie van Leeuwenhoek 107, 1451-73.

Marin M, Castro B, Gaitan A, Preisig O, Wingfield BD, Wingfield MJ, 2003. Relationships of Ceratocystis fimbriata isolates from Colombian coffee-growing regions based on molecular data and pathogenicity. Journal of Phytopathology 151, 395-405.

Mbenoun M, Wingfield MJ, Aimé D., Boyogueno B, Wingfield BD, Roux J, 2014. Molecular phylogenetic analyses reveal three new Ceratocystis species and provide evidence for geographic differentiation of the genus in Africa. Mycological Progress 13, 219-40.

Möller EM, Bahnweg G, Sandermann H, Geiger HH, 1992. A simple and efficient protocol for isolation of high molecular weight DNA from filamentous fungi, fruit bodies, and infected plant tissues. Nucleic Acids Research 20, 6115.

Nel WJ, Duong TA, Wingfield BD, Wingfield MJ, De Beer ZW, 2017. A new genus and species for the globally important, multi-host root pathogen Thielaviopsis basicola. Plant Pathology. https://doi.org/10.1111/ppa.12803.

Oliveira LS, Harrington TC, Ferreira MA et al., 2015a. Species or genotypes? Reassessment of four recently described species of the Ceratocystis wilt pathogen, $\mathrm{C}$. fimbriata, on Mangifera indica. Phytopathology 105, 1229-44.

Oliveira LS, Harrington TC, Freitas RG, McNew D, Alfenas AC, 2015b. Ceratocystis tiliae sp. nov., a wound pathogen on Tilia americana. Mycologia 107, 986-95.

Posada D, 2008. jModelTest: phylogenetic model averaging. Molecular Biology and Evolution 25, 1253-6.

Rayner RW, 1970. A Mycological Colour Chart. Kew, UK: Commonwealth Mycological Institute and British Mycological Society.

Roux J, Wingfield MJ, 2009. Ceratocystis species: emerging pathogens of non-native plantation Eucalyptus and Acacia species. Southern Forests 71, 115-20.

Schoch CL, Seifert KA, Huhndorf S et al., 2012. Nuclear ribosomal internal transcribed spacer (ITS) region as a universal DNA barcode marker for fungi. Proceedings of the National Academy of Sciences of the United States of America 109, 6241-6. 
Shimizu M, 1939. Black rot of dasheen. Pusan Customs Plant Inspection Report 1. Japan.

Steimel J, Engelbrecht CJB, Harrington TC, 2004. Development and characterization of microsatellite markers for the fungus Ceratocystis fimbriata. Molecular Ecology Notes 4, 215-8.

Swofford DL, 2003. paup*. Phylogenetic Analysis Using Parsimony (*And Other Methods). Version 4. Sunderland, MA, USA: Sinauer Associates.

Sy CM, 1956. Studies on the control of black rot (Ophiostoma fimbriatum) of sweet potato. Acta Phytopathologica Sinica 2, 81-95.

Tamura K, Dudley J, Nei M, Kumar S, 2007. mega 4: molecular evolutionary genetics analysis (MEGA) software version 4.0. Molecular Biology and Evolution 24, 1596-9.

Thorpe DJ, Harrington TC, Uchida JY, 2005. Pathogenicity, internal transcribed spacer-rDNA variation, and human dispersal of Ceratocystis fimbriata on the family Araceae. Phytopathology 95, 316-23.

Uchida JY, Aragaki M, 1979. Ceratocystis blight of Syngonium podophyllum. Plant Disease Reporter 63, 1053-6.

Van Wyk M, Wingfield BD, Al-Adawi AO, Rossetto CJ, Ito MF, Wingfield MJ, 2011. Two new Ceratocystis species associated with mango disease in Brazil. Mycotaxon 117, 381-404.

White TJ, Bruns T, Lee S, Taylor J, 1990. Amplification and direct sequencing of fungal ribosomal RNA genes for phylogenetics. In: Innis MA, Gelfand DH, Sninsky JJ, White TJ, eds. PCR Protocols: A Guide to Methods and Applications. New York, NY, USA: Academic Press, 315-22.

Xu B, Zheng XH, Guo WX, Zhou XP, He P, 2011. First report of pomegranate wilt caused by Ceratocystis fimbriata in Sichuan Province. Plant Disease 95, 776.

Yeh FC, Yang RC, Boyle T, 1999. popgene. Version 1.31. Microsoft Windows-based Freeware for Population Genetic Analysis. Edmonton, Canada: University of Alberta. 


\section{Supplementary Material}

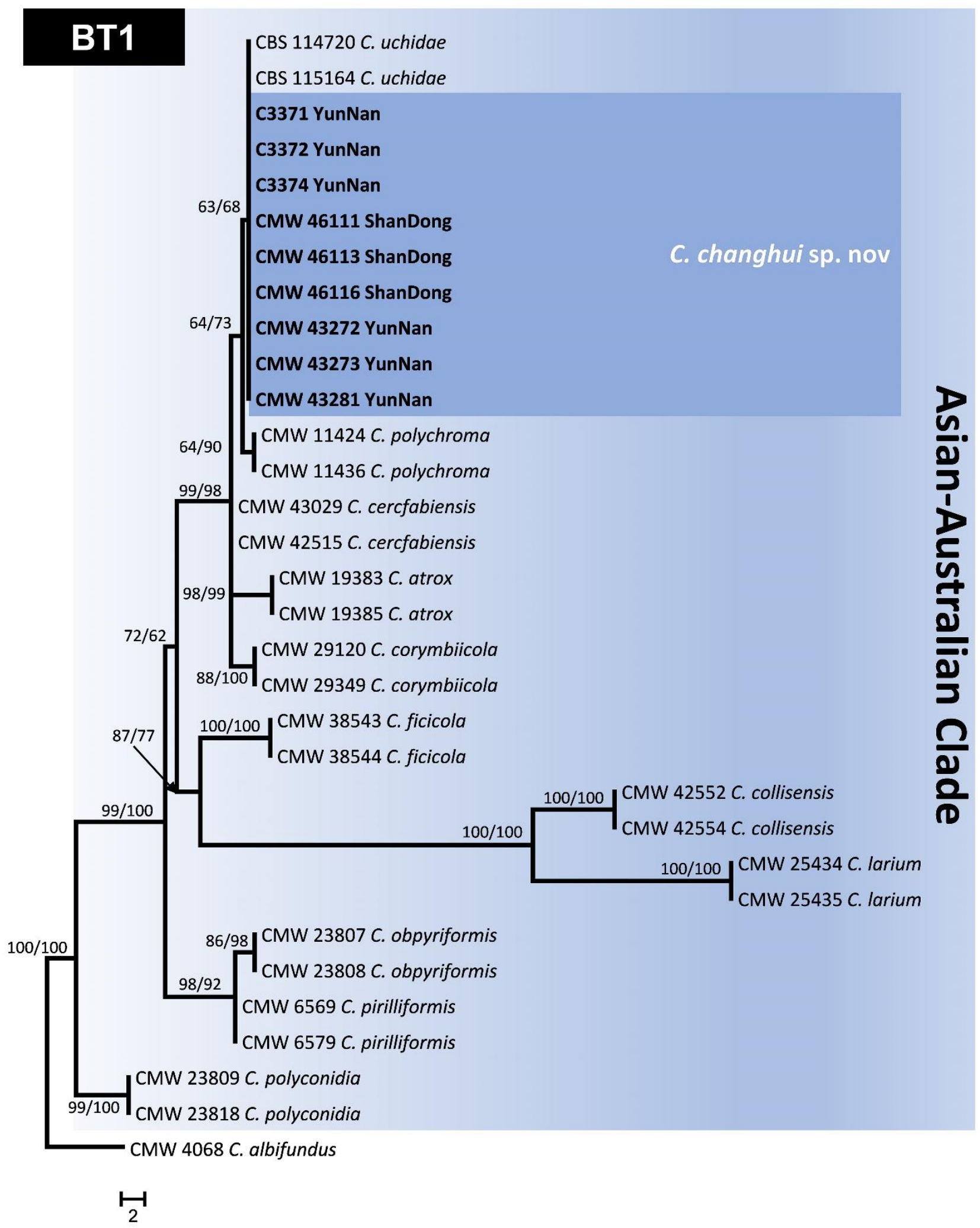

Figure S1. Phylogenetic trees based on maximum parsimony (MP) analysis of datasets of BT1 gene sequences for Ceratocystis species in the Asian-Australian clade. Isolates in bold and highlighted are the new species of Ceratocystis changhui described in this study. Bootstrap values $>50 \%$ for MP and maximum likelihood (ML) are presented above branches as MP/ML, bootstrap values absent are not shown or marked with -. The scale bar indicates 2 changes. 


\section{TEF}

C3371 YunNan

C3372 YunNan

C3374 YunNan

CMW 46111 ShanDong

CMW 46113 ShanDong

C. changhui sp. nov

$61 /-$

CMW 46116 ShanDong

CMW 43272 YunNan

CMW 43273 YunNan

CMW 43281 YunNan

$84 / 92$

CMW 43029 C. cercfabiensis

CMW 42515 C. cercfabiensis

CBS 115164 C. uchidae

$64 / 98$

CBS 114720 C. uchidae

CMW 29349 C. corymbiicola

$100 / *$

CMW 29120 C. corymbiicola

82/98 CMW 19383 C. atrox

96/71 CMW 19385 C. atrox

94/- ICMW 11424 C. polychroma

MW 11436 C. polychroma

100/95 CMW 25434 C. larium

73/98 LMW 42552 C. collisensis

CMW 42554 C. collisensis

93/92 100/100 CMW 23807 C. obpyriformis

CMW 23808 C. obpyriformis

$100 / 72$

90/82

62/- $C M W 23809$

CMW 23818 C. polyconidia

CMW 6579 C. pirilliformis

CMW 6569 C. pirilliformis

100/100 CMW 38543 C. ficicola

CMW 38544 C. ficicola

CMW 4068 C. albifundus

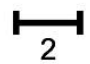

Figure S2. Phylogenetic trees based on maximum parsimony (MP) analysis of datasets of TEF-1 $\alpha$ gene sequences for Ceratocystis species in the Asian-Australian clade. Isolates in bold and highlighted are the new species of Ceratocystis changhui described in this study. Bootstrag values $>50 \%$ for MP and maximum likelihood (ML) are presented above branches as MP/ML, bootstrap values absent are not shown or marked with -. The scale bar indicates 2 changes. 


\section{MS204}

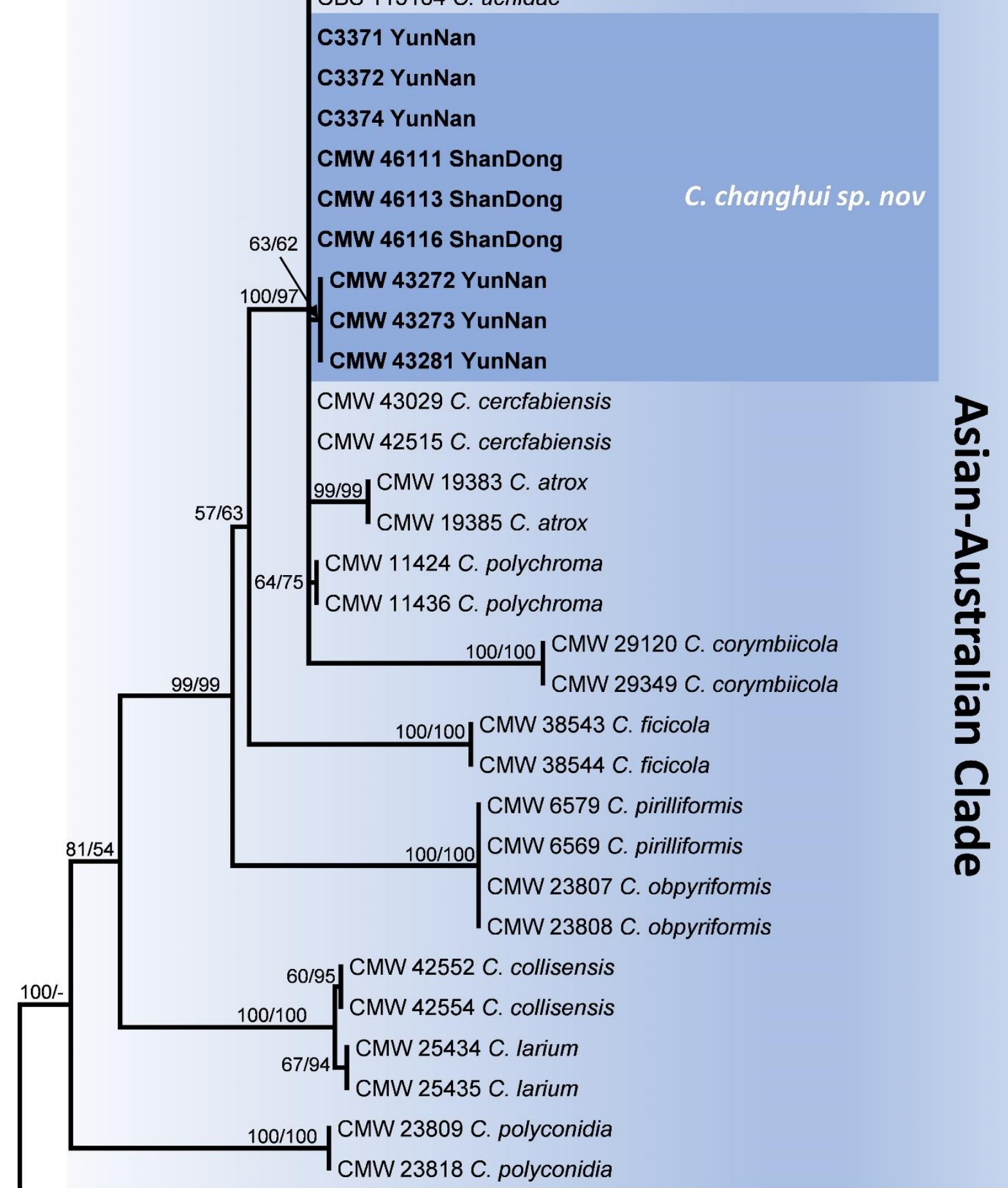

CMW 4068 C. albifundus

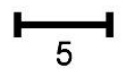

Figure S3. Phylogenetic trees based on maximum parsimony (MP) analysis of datasets of MS204 gene sequences for Ceratocystis species in the Asian-Australian clade. Isolates in bold and highlighted are the new species of Ceratocystis changhui described in this study. Bootstrap values $>5030$ for MP and maximum likelihood (ML) are presented above branches as MP/ML, bootstrap values absent are not shown or marked with -. The scale bar indicates 5 changes. 


\section{RPBII}

63/84 CBS 114720 C. uchidae

CBS 115164 C. uchidae

C3371 YunNan

C3372 YunNan

C3374 YunNan

CMW 46111 ShanDong

CMW 46113 ShanDong

C. changhui sp. nov

CMW 46116 ShanDong

CMW 43272 YunNan

CMW 43273 YunNan

CMW 43281 YunNan

CMW 43029 C. cercfabiensis

98/97

$96 / 90$

CMW 42515 C. cercfabiensis

99/100 CMW 19383 C. atrox

CMW 19385 C. atrox

99/99 CMW 11424 C. polychroma

CMW 11436 C. polychroma

88/95 CMW 29120 C. corymbiicola

CMW 29349 C. corymbiicola

100/100 CMW 38543 C. ficicola

CMW 38544 C. ficicola

CMW 23807 C. obpyriformis

CMW 23808 C. obpyriformis

CMW 6569 C. pirilliformis

CMW 6579 C. pirilliformis

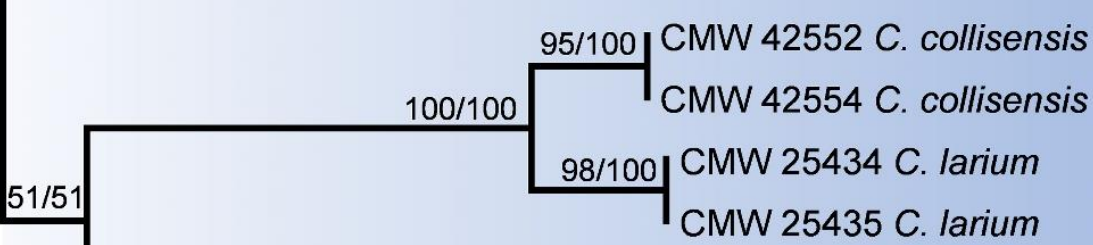

92/100 CMW 23809 C. polyconidia

CMW 23818 C. polyconidia

CMW 4068 C. albifundus

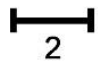

Figure S4. Phylogenetic trees based on maximum parsimony (MP) analysis of datasets of RPBIl gene sequences for Ceratocystis species in the Asian-Australian clade. Isolates in bold and highlighted are the new species of Ceratocystis changhui described in this study. Bootstrap values $>50 \%$ for MP and maximum likelihood (ML) are presented above branches as MPPML, bootstrap values absent are not shown or marked with -. The scale bar indicates 2 changes. 

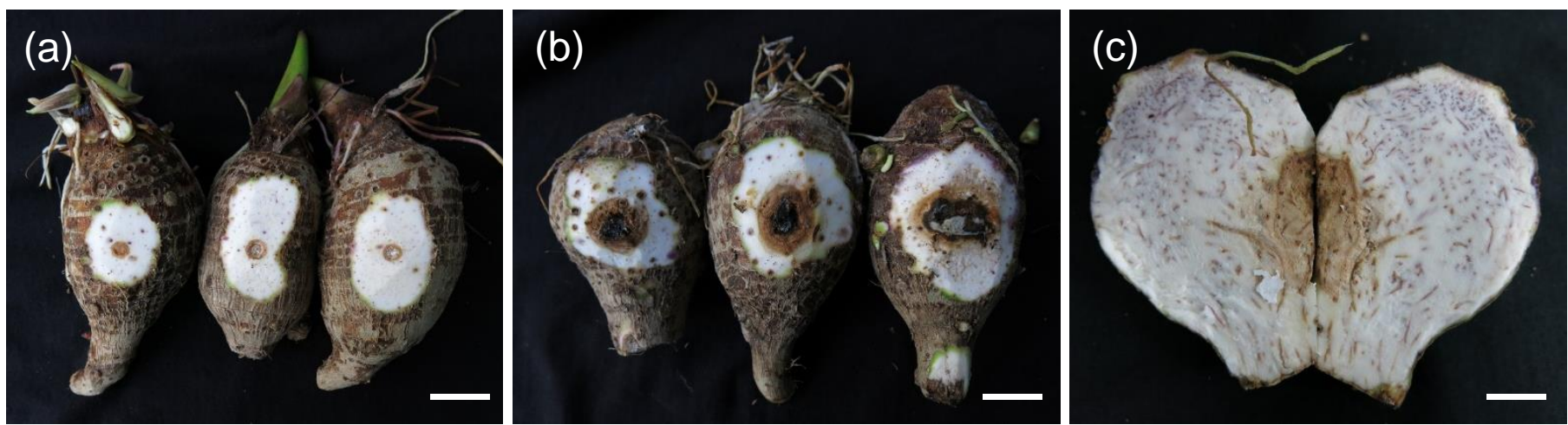

Figure S5. Symptoms after inoculations of Colocasia esculenta corms with Ceratocystis changhui sp. nov. (Koch's postulates trials); (a) negative control showing wounds but the absence of lesions; (b) inoculation with C. changhui (CMW 43280), showing the lesions on the corm; (c) inoculation with C. changhui (CMW 43281), showing lesions on the longitudinal section of the corm. Bars: $a, b=20 \mathrm{~mm}$. 
Supplementary Table 1 List of Ceratocystis isolates included in the microsatellite study and the allele scoring results

\begin{tabular}{|c|c|c|c|c|c|c|c|c|c|c|c|c|c|c|c|c|c|c|c|c|c|c|c|c|c|c|c|}
\hline Isolate & pecies & Host & cation & MLG & AF2 & AF3 & AF4 & AF5 & AF6 & AF7 & AF9 & $\mathrm{AF} 1$ & $\begin{array}{l}\text { CA } \\
\text { A10 }\end{array}$ & $\begin{array}{l}\text { CA } \\
\text { A38 }\end{array}$ & $\begin{array}{l}\text { GA } \\
\text { CA } \\
650 \\
\end{array}$ & $\begin{array}{l}\text { AG } \\
7 / \mathrm{A} \\
\mathrm{G} 8 \\
\end{array}$ & $\begin{array}{l}\text { CF1 } \\
3 / \mathrm{C} \\
\text { F14 } \\
\end{array}$ & $\begin{array}{l}\text { CF2 } \\
3 / \mathrm{C} \\
\mathrm{F} 24 \\
\end{array}$ & $\begin{array}{l}\mathrm{CA} \\
\mathrm{A} 9\end{array}$ & $\begin{array}{l}\text { AA } \\
\text { G8 }\end{array}$ & $\begin{array}{l}\text { CA } \\
\text { T1 }\end{array}$ & $\begin{array}{l}\mathrm{AG} \\
1 / \mathrm{A} \\
\mathrm{G} 2 \\
\end{array}$ & $\begin{array}{l}\mathrm{CA} \\
\mathrm{A} 80\end{array}$ & $\begin{array}{l}\text { CA } \\
\text { T9X }\end{array}$ & $\begin{array}{l}\text { CA } \\
\text { T3K }\end{array}$ & $\begin{array}{l}\text { CA } \\
\text { T12 } \\
00 \\
\end{array}$ & $\begin{array}{l}\mathrm{AA} \\
\mathrm{G} 9\end{array}$ \\
\hline CERC2471 & C. cercfabiensis & Eucalyptus & FuJian & GT1 & 206 & 194 & 237 & 226 & 294 & 328 & 401 & 444 & 126 & 136 & 182 & 278 & 431 & 157 & 160 & 174 & 232 & 266 & 304 & 270 & 306 & 355 & 392 \\
\hline CERC2473 & cercfabiensis & Eucalyptus & FuJian & GT1 & 206 & 194 & 237 & 226 & 294 & 328 & 401 & 444 & 126 & 136 & 182 & 278 & 431 & 157 & 160 & 174 & 232 & 266 & 304 & 270 & 306 & 355 & 392 \\
\hline CERC2475 & C. cercfabiensis & Eucalyptus & FuJian & GT1 & 206 & 194 & 237 & 226 & 294 & 328 & 401 & 444 & 126 & 136 & 182 & 278 & 431 & 157 & 160 & 174 & 232 & 266 & 304 & 270 & 306 & 355 & 392 \\
\hline CERC2335 & C. cercfabiensis & Eucalyptus & GuangXi & GT1 & 206 & 194 & 237 & 226 & 294 & 328 & 401 & 444 & 126 & 136 & 182 & 278 & 431 & 157 & 160 & 174 & 232 & 266 & 304 & 270 & 306 & 355 & 392 \\
\hline CERC2347 & C. cercfabiensis & Eucalyptus & GuangXi & GT1 & 206 & 194 & 237 & 226 & 294 & 328 & 401 & 444 & 126 & 136 & 182 & 278 & 431 & 157 & 160 & 174 & 232 & 266 & 304 & 270 & 306 & 355 & 392 \\
\hline CERC2381 & C. cercfabiensis & Eucalyptus & GuangXi & GT1 & 206 & 194 & 237 & 226 & 294 & 328 & 401 & 444 & 126 & 136 & 182 & 278 & 431 & 157 & 160 & 174 & 232 & 266 & 304 & 270 & 306 & 355 & 392 \\
\hline CERC2383 & C. cercfabiensis & Eucalyptus & GuangXi & GT1 & 206 & 194 & 237 & 226 & 294 & 328 & 401 & 444 & 126 & 136 & 182 & 278 & 431 & 157 & 160 & 174 & 232 & 266 & 304 & 270 & 306 & 355 & 392 \\
\hline CERC2800 & C. cercfabiensis & Eucalyptus & GuangXi & GT1 & 206 & 194 & 237 & 226 & 294 & 328 & 401 & 444 & 126 & 136 & 182 & 278 & 431 & 157 & 160 & 174 & 232 & 266 & 304 & 270 & 306 & 355 & 392 \\
\hline CERC2807 & C. cercfabiensis & Eucalyptus & GuangXi & GT1 & 206 & 194 & 237 & 226 & 294 & 328 & 401 & 444 & 126 & 136 & 182 & 278 & 431 & 157 & 160 & 174 & 232 & 266 & 304 & 270 & 306 & 355 & 392 \\
\hline CERC2817 & C. cercfabiensis & Eucalyptus & GuangXi & GT1 & 206 & 194 & 237 & 226 & 294 & 328 & 401 & 444 & 126 & 136 & 182 & 278 & 431 & 157 & 160 & 174 & 232 & 266 & 304 & 270 & 306 & 355 & 392 \\
\hline CERC2825 & C. cercfabiensis & Eucalyptus & GuangXi & GT1 & 206 & 194 & 237 & 226 & 294 & 328 & 401 & 444 & 126 & 136 & 182 & 278 & 431 & 157 & 160 & 174 & 232 & 266 & 304 & 270 & 306 & 355 & 392 \\
\hline CERC2323 & C. cercfabiensis & Eucalyptus & GuangXi & GT2 & 206 & 194 & 237 & 226 & 294 & 328 & 401 & 444 & 126 & 136 & 182 & 278 & 431 & 157 & 160 & 174 & 232 & 266 & 304 & 270 & 306 & 355 & 389 \\
\hline CERC2385 & C. cercfabiensis & Eucalyptus & GuangXi & GT2 & 206 & 194 & 237 & 226 & 294 & 328 & 401 & 444 & 126 & 136 & 182 & 278 & 431 & 157 & 160 & 174 & 232 & 266 & 304 & 270 & 306 & 355 & 389 \\
\hline CERC2330 & C. cercfabiensis & Eucalyptus & GuangXi & GT3 & 206 & 194 & 237 & 226 & 294 & 328 & 401 & 444 & 126 & 136 & 182 & 278 & 431 & 157 & 157 & 174 & 232 & 266 & 304 & 270 & 306 & 355 & 392 \\
\hline CERC2646 & C. cercfabiensis & Eucalyptus & GuangXi & GT3 & 206 & 194 & 237 & 226 & 294 & 328 & 401 & 444 & 126 & 136 & 182 & 278 & 431 & 157 & 157 & 174 & 232 & 266 & 304 & 270 & 306 & 355 & 392 \\
\hline CERC2325 & C. cercfabiensis & Eucalyptus & GuangXi & GT4 & 206 & 194 & 237 & 226 & 294 & 328 & 401 & 444 & 126 & 143 & 182 & 278 & 431 & 157 & 160 & 174 & 232 & 266 & 304 & 270 & 306 & 355 & 392 \\
\hline CERC2570 & C. cercfabiensis & Eucalyptus & GuangDong & GT5 & 206 & 194 & 237 & 226 & 291 & 328 & 401 & 444 & 126 & 136 & 182 & 278 & 431 & 157 & 160 & 174 & 232 & 266 & 304 & 270 & 306 & 355 & 392 \\
\hline CERC2686 & C. cercfabiensis & Eucalyptus & GuangDong & GT6 & 206 & 194 & 237 & 226 & 291 & 334 & 401 & 447 & 126 & 136 & 182 & 278 & 431 & 157 & 160 & 174 & 232 & 266 & 304 & 270 & 306 & 355 & 392 \\
\hline CERC5520 & C. cercfabiensis & Eucalyptus & YunNan & GT7 & 206 & 194 & 237 & 226 & 288 & 328 & 401 & 444 & 126 & 136 & 182 & 278 & 431 & 157 & 160 & 174 & 232 & 266 & 304 & 270 & 306 & 355 & 392 \\
\hline CERC5526 & C. cercfabiensis & Eucalyptus & YunNan & GT7 & 206 & 194 & 237 & 226 & 288 & 328 & 401 & 444 & 126 & 136 & 182 & 278 & 431 & 157 & 160 & 174 & 232 & 266 & 304 & 270 & 306 & 355 & 392 \\
\hline CERC5529 & C. cercfabiensis & Eucalyptus & YunNan & GT7 & 206 & 194 & 237 & 226 & 288 & 328 & 401 & 444 & 126 & 136 & 182 & 278 & 431 & 157 & 160 & 174 & 232 & 266 & 304 & 270 & 306 & 355 & 392 \\
\hline CERC6276 & C. cercfabiensis & Eucalyptus & YunNan & GT7 & 206 & 194 & 237 & 226 & 288 & 328 & 401 & 444 & 126 & 136 & 182 & 278 & 431 & 157 & 160 & 174 & 232 & 266 & 304 & 270 & 306 & 355 & 392 \\
\hline CERC6267 & C. cercfabiensis & Eucalyptus & YunNan & GT8 & 206 & 194 & 237 & 226 & 288 & 328 & 401 & 444 & 126 & 136 & 182 & 278 & 431 & 157 & 160 & 174 & 232 & 266 & 304 & 270 & $\mathrm{M}^{2}$ & 355 & 392 \\
\hline CERC5524 & C. cercfabiensis & Eucalyptus & YunNan & GT9 & 206 & 194 & 237 & 226 & 288 & 328 & 401 & 444 & M & 136 & 182 & 278 & 431 & 157 & 160 & 174 & 232 & 266 & 304 & 270 & M & 355 & 397 \\
\hline CERC2554 & C. cercfabiensis & Eucalyptus & GuangDong & GT10 & 206 & 194 & 237 & 226 & $\mathrm{~N}^{1}$ & 328 & 401 & 444 & 126 & 136 & 182 & 278 & 431 & 157 & 157 & 174 & 232 & 266 & 304 & 270 & 306 & 355 & 392 \\
\hline CERC2687 & C. cercfabiensis & Eucalyptus & GuangDong & GT11 & 206 & 194 & 237 & 226 & $\mathrm{~N}$ & 334 & $\mathrm{~N}$ & 447 & 126 & 136 & 182 & 278 & 431 & 157 & 160 & 174 & 232 & 266 & 304 & 270 & 306 & 355 & 392 \\
\hline CERC2333 & C. cercfabiensis & Eucalyptus & GuangXi & GT12 & 206 & 194 & 240 & 226 & 294 & 328 & 401 & 444 & 126 & 136 & 182 & 278 & 431 & 157 & 160 & 174 & 232 & 266 & 304 & 270 & 306 & 355 & 392 \\
\hline CERC2358 & C. cercfabiensis & Eucalyptus & GuangXi & GT12 & 206 & 194 & 240 & 226 & 294 & 328 & 401 & 444 & 126 & 136 & 182 & 278 & 431 & 157 & 160 & 174 & 232 & 266 & 304 & 270 & 306 & 355 & 392 \\
\hline CERC2368 & C. cercfabiensis & Eucalyptus & GuangXi & GT12 & 206 & 194 & 240 & 226 & 294 & 328 & 401 & 444 & 126 & 136 & 182 & 278 & 431 & 157 & 160 & 174 & 232 & 266 & 304 & 270 & 306 & 355 & 392 \\
\hline CERC2553 & C. cercfabiensis & Eucalyptus & GuangDong & GT13 & 206 & 194 & 240 & 226 & 294 & 328 & 401 & 444 & 126 & 136 & 182 & 278 & 431 & 157 & 157 & 174 & 232 & 266 & 304 & 270 & 306 & 355 & 392 \\
\hline CERC2581 & C. cercfabiensis & Eucalyptus & GuangDong & GT14 & 206 & 194 & 240 & 226 & 294 & 328 & 401 & 444 & 129 & 136 & 182 & 278 & 431 & 157 & 160 & 174 & 232 & 266 & 304 & 270 & 306 & 355 & 392 \\
\hline CERC2586 & C. cercfabiensis & Eucalyptus & GuangDong & GT14 & 206 & 194 & 240 & 226 & 294 & 328 & 401 & 444 & 129 & 136 & 182 & 278 & 431 & 157 & 160 & 174 & 232 & 266 & 304 & 270 & 306 & 355 & 392 \\
\hline CERC2576 & C. cercfabiensis & Eucalyptus & GuangDong & GT15 & 206 & 194 & 240 & 226 & 294 & 328 & 401 & 444 & 129 & 136 & 182 & 278 & 431 & 157 & 160 & 174 & 232 & 266 & 304 & 270 & 306 & 355 & 384 \\
\hline CERC2317 & C. cercfabiensis & Eucalyptus & GuangXi & GT16 & 206 & 194 & 240 & 226 & 291 & 328 & 401 & 444 & 126 & 136 & 182 & 278 & 431 & 157 & 160 & 174 & 232 & 266 & 304 & 270 & 306 & 355 & 392 \\
\hline CERC2552 & C. cercfabiensis & Eucalyptus & GuangDong & GT17 & 203 & 194 & 237 & 226 & 294 & 328 & 401 & 444 & 126 & 136 & 182 & 278 & 431 & 157 & 160 & 174 & 232 & 266 & 304 & 270 & 306 & 355 & 392 \\
\hline CERC2170 & C. cercfabiensis & Eucalyptus & HaiNan & GT17 & 203 & 194 & 237 & 226 & 294 & 328 & 401 & 444 & 126 & 136 & 182 & 278 & 431 & 157 & 160 & 174 & 232 & 266 & 304 & 270 & 306 & 355 & 392 \\
\hline CERC2177 & C. cercfabiensis & Eucalyptus & HaiNan & GT17 & 203 & 194 & 237 & 226 & 294 & 328 & 401 & 444 & 126 & 136 & 182 & 278 & 431 & 157 & 160 & 174 & 232 & 266 & 304 & 270 & 306 & 355 & 392 \\
\hline
\end{tabular}




\begin{tabular}{|c|c|c|c|c|c|c|c|c|c|c|c|c|c|c|c|c|c|c|c|c|c|c|c|c|c|c|c|}
\hline CERC2549 & C. cercfabiensis & Eucalyptus & GuangDong & GT18 & 203 & 194 & 237 & 226 & 294 & 328 & 401 & 444 & 126 & 136 & 182 & 278 & 431 & 157 & 157 & 174 & 232 & 266 & 304 & 270 & 306 & 355 & 392 \\
\hline CERC2350 & C. cercfabiensis & Eucalyptus & GuangXi & GT19 & 203 & 194 & 240 & 226 & 294 & 328 & 401 & 444 & 126 & 136 & 182 & 278 & 431 & 157 & 160 & 171 & 232 & 266 & 304 & 270 & 306 & 355 & 392 \\
\hline CERC2345 & C. cercfabiensis & Eucalyptus & GuangXi & GT20 & 203 & 194 & 240 & 226 & 294 & 328 & 401 & 444 & 126 & 136 & 182 & 278 & 431 & 157 & 157 & 174 & 232 & 266 & 304 & 270 & 306 & 355 & 392 \\
\hline CERC7516 & C. changhui & $\begin{array}{l}\text { Colocasia } \\
\text { esculenta }\end{array}$ & ShanDong & GT21 & 223 & 194 & 243 & 226 & 270 & 328 & 401 & 444 & 126 & 136 & 182 & 278 & 431 & 157 & 147 & 171 & 232 & 266 & 292 & 267 & 306 & 355 & 392 \\
\hline CERC7519 & C. changhui & $\begin{array}{l}\text { Colocasia } \\
\text { esculenta }\end{array}$ & ShanDong & GT21 & 223 & 194 & 243 & 226 & 270 & 328 & 401 & 444 & 126 & 136 & 182 & 278 & 431 & 157 & 147 & 171 & 232 & 266 & 292 & 267 & 306 & 355 & 392 \\
\hline CERC7520 & C. changhui & $\begin{array}{l}\text { Colocasia } \\
\text { esculenta }\end{array}$ & ShanDong & GT21 & 223 & 194 & 243 & 226 & 270 & 328 & 401 & 444 & 126 & 136 & 182 & 278 & 431 & 157 & 147 & 171 & 232 & 266 & 292 & 267 & 306 & 355 & 392 \\
\hline CERC7524 & C. changhui & $\begin{array}{l}\text { Colocasia } \\
\text { esculenta }\end{array}$ & ShanDong & GT21 & 223 & 194 & 243 & 226 & 270 & 328 & 401 & 444 & 126 & 136 & 182 & 278 & 431 & 157 & 147 & 171 & 232 & 266 & 292 & 267 & 306 & 355 & 392 \\
\hline CERC7529 & C. changhui & $\begin{array}{l}\text { Colocasia } \\
\text { esculenta }\end{array}$ & ShanDong & GT21 & 223 & 194 & 243 & 226 & 270 & 328 & 401 & 444 & 126 & 136 & 182 & 278 & 431 & 157 & 147 & 171 & 232 & 266 & 292 & 267 & 306 & 355 & 392 \\
\hline CERC7531 & C. changhui & $\begin{array}{l}\text { Colocasia } \\
\text { esculenta }\end{array}$ & ShanDong & GT21 & 223 & 194 & 243 & 226 & 270 & 328 & 401 & 444 & 126 & 136 & 182 & 278 & 431 & 157 & 147 & 171 & 232 & 266 & 292 & 267 & 306 & 355 & 392 \\
\hline CERC7532 & C. changhui & $\begin{array}{l}\text { Colocasia } \\
\text { esculenta }\end{array}$ & ShanDong & GT21 & 223 & 194 & 243 & 226 & 270 & 328 & 401 & 444 & 126 & 136 & 182 & 278 & 431 & 157 & 147 & 171 & 232 & 266 & 292 & 267 & 306 & 355 & 392 \\
\hline CERC7533 & C. changhui & $\begin{array}{l}\text { Colocasia } \\
\text { esculenta }\end{array}$ & ShanDong & GT21 & 223 & 194 & 243 & 226 & 270 & 328 & 401 & 444 & 126 & 136 & 182 & 278 & 431 & 157 & 147 & 171 & 232 & 266 & 292 & 267 & 306 & 355 & 392 \\
\hline CERC7534 & C. changhui & $\begin{array}{l}\text { Colocasia } \\
\text { esculenta }\end{array}$ & ShanDong & GT21 & 223 & 194 & 243 & 226 & 270 & 328 & 401 & 444 & 126 & 136 & 182 & 278 & 431 & 157 & 147 & 171 & 232 & 266 & 292 & 267 & 306 & 355 & 392 \\
\hline CERC7536 & C. changhui & $\begin{array}{l}\text { Colocasia } \\
\text { esculenta }\end{array}$ & ShanDong & GT21 & 223 & 194 & 243 & 226 & 270 & 328 & 401 & 444 & 126 & 136 & 182 & 278 & 431 & 157 & 147 & 171 & 232 & 266 & 292 & 267 & 306 & 355 & 392 \\
\hline CERC7538 & C. changhui & $\begin{array}{l}\text { Colocasia } \\
\text { esculenta }\end{array}$ & ShanDong & GT21 & 223 & 194 & 243 & 226 & 270 & 328 & 401 & 444 & 126 & 136 & 182 & 278 & 431 & 157 & 147 & 171 & 232 & 266 & 292 & 267 & 306 & 355 & 392 \\
\hline CERC7541 & C. changhui & $\begin{array}{l}\text { Colocasia } \\
\text { esculenta }\end{array}$ & ShanDong & GT21 & 223 & 194 & 243 & 226 & 270 & 328 & 401 & 444 & 126 & 136 & 182 & 278 & 431 & 157 & 147 & 171 & 232 & 266 & 292 & 267 & 306 & 355 & 392 \\
\hline CERC7542 & C. changhui & $\begin{array}{l}\text { Colocasia } \\
\text { esculenta }\end{array}$ & ShanDong & GT21 & 223 & 194 & 243 & 226 & 270 & 328 & 401 & 444 & 126 & 136 & 182 & 278 & 431 & 157 & 147 & 171 & 232 & 266 & 292 & 267 & 306 & 355 & 392 \\
\hline CERC7543 & C. changhui & $\begin{array}{l}\text { Colocasia } \\
\text { esculenta }\end{array}$ & ShanDong & GT21 & 223 & 194 & 243 & 226 & 270 & 328 & 401 & 444 & 126 & 136 & 182 & 278 & 431 & 157 & 147 & 171 & 232 & 266 & 292 & 267 & 306 & 355 & 392 \\
\hline CERC7544 & C. changhui & $\begin{array}{l}\text { Colocasia } \\
\text { esculenta }\end{array}$ & ShanDong & GT21 & 223 & 194 & 243 & 226 & 270 & 328 & 401 & 444 & 126 & 136 & 182 & 278 & 431 & 157 & 147 & 171 & 232 & 266 & 292 & 267 & 306 & 355 & 392 \\
\hline CERC7527 & C. changhui & $\begin{array}{l}\text { Colocasia } \\
\text { esculenta }\end{array}$ & ShanDong & GT22 & 223 & 194 & 243 & 226 & 270 & 328 & 401 & 444 & 126 & 136 & 182 & 278 & 431 & 157 & 147 & 171 & 232 & 266 & 292 & 267 & M & 355 & 397 \\
\hline CERC7530 & C. changhui & $\begin{array}{l}\text { Colocasia } \\
\text { esculenta }\end{array}$ & ShanDong & GT22 & 223 & 194 & 243 & 226 & 270 & 328 & 401 & 444 & 126 & 136 & 182 & 278 & 431 & 157 & 147 & 171 & 232 & 266 & 292 & 267 & M & 355 & 397 \\
\hline CERC3601 & C. changhui & $\begin{array}{l}\text { Colocasia } \\
\text { esculenta }\end{array}$ & YunNan & GT23 & 220 & 194 & 237 & 226 & 270 & 328 & 401 & 444 & 126 & 143 & 182 & 278 & 431 & 157 & 147 & 171 & 232 & 266 & 304 & 267 & 306 & 355 & 392 \\
\hline CERC3602 & C. changhui & $\begin{array}{l}\text { Colocasia } \\
\text { esculenta }\end{array}$ & YunNan & GT23 & 220 & 194 & 237 & 226 & 270 & 328 & 401 & 444 & 126 & 143 & 182 & 278 & 431 & 157 & 147 & 171 & 232 & 266 & 304 & 267 & 306 & 355 & 392 \\
\hline CERC3604 & C. changhui & $\begin{array}{l}\text { Colocasia } \\
\text { esculenta }\end{array}$ & YunNan & GT23 & 220 & 194 & 237 & 226 & 270 & 328 & 401 & 444 & 126 & 143 & 182 & 278 & 431 & 157 & 147 & 171 & 232 & 266 & 304 & 267 & 306 & 355 & 392 \\
\hline CERC3605 & C. changhui & $\begin{array}{l}\text { Colocasia } \\
\text { esculenta }\end{array}$ & YunNan & GT23 & 220 & 194 & 237 & 226 & 270 & 328 & 401 & 444 & 126 & 143 & 182 & 278 & 431 & 157 & 147 & 171 & 232 & 266 & 304 & 267 & 306 & 355 & 392 \\
\hline CERC3607 & C. changhui & $\begin{array}{l}\text { Colocasia } \\
\text { esculenta }\end{array}$ & YunNan & GT23 & 220 & 194 & 237 & 226 & 270 & 328 & 401 & 444 & 126 & 143 & 182 & 278 & 431 & 157 & 147 & 171 & 232 & 266 & 304 & 267 & 306 & 355 & 392 \\
\hline CERC3608 & C. changhui & $\begin{array}{l}\text { Colocasia } \\
\text { esculenta }\end{array}$ & YunNan & GT23 & 220 & 194 & 237 & 226 & 270 & 328 & 401 & 444 & 126 & 143 & 182 & 278 & 431 & 157 & 147 & 171 & 232 & 266 & 304 & 267 & 306 & 355 & 392 \\
\hline CERC3609 & C. changhui & $\begin{array}{l}\text { Colocasia } \\
\text { esculenta }\end{array}$ & YunNan & GT23 & 220 & 194 & 237 & 226 & 270 & 328 & 401 & 444 & 126 & 143 & 182 & 278 & 431 & 157 & 147 & 171 & 232 & 266 & 304 & 267 & 306 & 355 & 392 \\
\hline CERC3610 & C. changhui & $\begin{array}{l}\text { Colocasia } \\
\text { esculenta }\end{array}$ & YunNan & GT23 & 220 & 194 & 237 & 226 & 270 & 328 & 401 & 444 & 126 & 143 & 182 & 278 & 431 & 157 & 147 & 171 & 232 & 266 & 304 & 267 & 306 & 355 & 392 \\
\hline CERC3611 & C. changhui & $\begin{array}{l}\text { Colocasia } \\
\text { esculenta }\end{array}$ & YunNan & GT23 & 220 & 194 & 237 & 226 & 270 & 328 & 401 & 444 & 126 & 143 & 182 & 278 & 431 & 157 & 147 & 171 & 232 & 266 & 304 & 267 & 306 & 355 & 392 \\
\hline
\end{tabular}




\begin{tabular}{|c|c|c|c|c|c|c|c|c|c|c|c|c|c|c|c|c|c|c|c|c|c|c|c|c|c|c|c|}
\hline CERC3612 & C. changhui & $\begin{array}{l}\text { Colocasia } \\
\text { esculenta }\end{array}$ & YunNan & GT23 & 220 & 194 & 237 & 226 & 270 & 328 & 401 & 444 & 126 & 143 & 182 & 278 & 431 & 157 & 147 & 171 & 232 & 266 & 304 & 267 & 306 & 355 & 392 \\
\hline CERC3614 & C. changhui & $\begin{array}{l}\text { Colocasia } \\
\text { esculenta }\end{array}$ & YunNan & GT23 & 220 & 194 & 237 & 226 & 270 & 328 & 401 & 444 & 126 & 143 & 182 & 278 & 431 & 157 & 147 & 171 & 232 & 266 & 304 & 267 & 306 & 355 & 392 \\
\hline CERC3615 & C. changhui & $\begin{array}{l}\text { Colocasia } \\
\text { esculenta }\end{array}$ & YunNan & GT23 & 220 & 194 & 237 & 226 & 270 & 328 & 401 & 444 & 126 & 143 & 182 & 278 & 431 & 157 & 147 & 171 & 232 & 266 & 304 & 267 & 306 & 355 & 392 \\
\hline CERC3616 & C. changhui & $\begin{array}{l}\text { Colocasia } \\
\text { esculenta }\end{array}$ & YunNan & GT23 & 220 & 194 & 237 & 226 & 270 & 328 & 401 & 444 & 126 & 143 & 182 & 278 & 431 & 157 & 147 & 171 & 232 & 266 & 304 & 267 & 306 & 355 & 392 \\
\hline CERC3606 & C. changhui & $\begin{array}{l}\text { Colocasia } \\
\text { esculenta }\end{array}$ & YunNan & GT24 & 220 & 194 & 237 & 226 & 270 & 328 & 401 & 444 & 126 & 143 & 182 & 278 & 431 & 157 & 147 & 171 & 232 & 266 & 304 & 267 & 322 & 355 & 397 \\
\hline C3371 & $\begin{array}{l}\text { Ceratocystis sp. } \\
\mathrm{Y}^{3}\end{array}$ & Eucalyptus & YunNan & GT25 & 232 & 194 & 243 & 226 & 270 & 328 & 401 & 444 & 126 & 136 & 182 & M & 431 & 157 & 147 & 171 & 232 & 266 & 292 & 267 & 306 & 355 & 392 \\
\hline C3372 & $\begin{array}{l}\text { Ceeratocystis sp. } \\
\mathrm{Y}^{3}\end{array}$ & Eucalyptus & YunNan & GT25 & 232 & 194 & 243 & 226 & 270 & 328 & 401 & 444 & 126 & 136 & 182 & M & 431 & 157 & 147 & 171 & 232 & 266 & 292 & 267 & 306 & 355 & 392 \\
\hline C3373 & $\begin{array}{l}\text { Ceratocystis sp. } \\
\mathrm{Y}^{3}\end{array}$ & Eucalyptus & YunNan & GT25 & 232 & 194 & 243 & 226 & 270 & 328 & 401 & 444 & 126 & 136 & 182 & M & 431 & 157 & 147 & 171 & 232 & 266 & 292 & 267 & 306 & 355 & 392 \\
\hline C3374 & $\begin{array}{l}\text { Ceratocystis sp. } \\
\mathrm{Y}^{3}\end{array}$ & Eucalyptus & YunNan & GT25 & 232 & 194 & 243 & 226 & 270 & 328 & 401 & 444 & 126 & 136 & 182 & M & 431 & 157 & 147 & 171 & 232 & 266 & 292 & 267 & 306 & 355 & 392 \\
\hline C3375 & $\begin{array}{l}\text { Ceratocystis sp. } \\
\mathrm{Y}^{3}\end{array}$ & Eucalyptus & YunNan & GT25 & 232 & 194 & 243 & 226 & 270 & 328 & 401 & 444 & 126 & 136 & 182 & M & 431 & 157 & 147 & 171 & 232 & 266 & 292 & 267 & 306 & 355 & 392 \\
\hline C3376 & $\begin{array}{l}\text { Ceratocystis sp. } \\
\mathrm{Y}^{3}\end{array}$ & Eucalyptus & YunNan & GT25 & 232 & 194 & 243 & 226 & 270 & 328 & 401 & 444 & 126 & 136 & 182 & M & 431 & 157 & 147 & 171 & 232 & 266 & 292 & 267 & 306 & 355 & 392 \\
\hline CBS 115164 & C. uchidae & $\begin{array}{l}\text { Colocasia } \\
\text { esculenta }\end{array}$ & Hawaii & GT26 & 219 & 194 & 249 & 226 & 270 & 329 & 401 & 444 & 126 & 139 & 182 & 278 & 446 & 157 & 147 & 171 & 232 & 266 & 284 & 267 & 306 & 355 & 392 \\
\hline CBS 114720 & C. uchidae & $\begin{array}{l}\text { Colocasia } \\
\text { esculenta }\end{array}$ & Hawaii & GT26 & 219 & 194 & 249 & 226 & 270 & 329 & 401 & 444 & 126 & 139 & 182 & 278 & 446 & 157 & 147 & 171 & 232 & 266 & 284 & 267 & 306 & 355 & 392 \\
\hline CMW19383 & C. atrox & $\begin{array}{l}\text { Eucalyptus } \\
\text { grandis }\end{array}$ & Australia & GT27 & 192 & 194 & 231 & 226 & 270 & 319 & 401 & 452 & 129 & 124 & 191 & 280 & 407 & 157 & M & 177 & 225 & 266 & 280 & 270 & 306 & 355 & 386 \\
\hline CMW19385 & C. atrox & $\begin{array}{l}\text { Eucalyptus } \\
\text { grandis }\end{array}$ & Australia & GT27 & 192 & 194 & 231 & 226 & 270 & 319 & 401 & 452 & 129 & 124 & 191 & 280 & 407 & 157 & M & 177 & 225 & 266 & 280 & 270 & 306 & 355 & 386 \\
\hline CMW6579 & C. pirilliformis & $\begin{array}{l}\text { Eucalyptus } \\
\text { nitens }\end{array}$ & Australia & GT28 & 192 & 194 & 234 & 230 & 270 & 340 & 399 & 450 & 126 & 93 & 177 & 278 & 382 & 157 & 140 & 159 & 219 & 266 & 304 & 267 & 306 & 357 & 384 \\
\hline CMW6569 & C. pirilliformis & $\begin{array}{l}\text { Eucalyptus } \\
\text { nitens }\end{array}$ & Australia & GT29 & 206 & 194 & 231 & 230 & 270 & 340 & 399 & 450 & 129 & 93 & 177 & 278 & 382 & 157 & 140 & 183 & 219 & 266 & 304 & 267 & 306 & 357 & 384 \\
\hline CMW23807 & C. obpyriformis & $\begin{array}{l}\text { Acacia } \\
\text { mearnsii }\end{array}$ & South Africa & GT30 & 192 & 194 & 228 & 230 & 252 & 340 & 399 & 452 & 126 & 93 & 177 & 278 & 382 & 157 & 140 & 177 & 219 & 266 & 304 & 270 & 306 & 357 & 384 \\
\hline CMW23808 & C. obpyriformis & $\begin{array}{l}\text { Acacia } \\
\text { mearnsii }\end{array}$ & South Africa & GT31 & 192 & 194 & 228 & 230 & 252 & 340 & 399 & 450 & 126 & 93 & 177 & 278 & 382 & 157 & 140 & 177 & 219 & 266 & 304 & 270 & 306 & 357 & 384 \\
\hline CMW25435 & C. larium & $\begin{array}{l}\text { Styrax } \\
\text { benzoin }\end{array}$ & Indonesia & GT32 & 203 & 194 & 218 & 234 & 270 & 310 & 422 & 476 & 135 & 130 & 177 & 278 & 431 & 160 & 157 & 156 & 221 & 266 & 263 & 283 & 319 & 379 & 401 \\
\hline CMW25434 & C. larium & $\begin{array}{l}\text { Styrax } \\
\text { benzoin }\end{array}$ & Indonesia & GT33 & 203 & 194 & 218 & 234 & $\mathrm{M}$ & 310 & 422 & 476 & 135 & 130 & 177 & 278 & 431 & 160 & 157 & 156 & 221 & 266 & 263 & 283 & $\mathrm{~N}$ & 379 & 401 \\
\hline CMW11436 & C. polychroma & $\begin{array}{l}\text { Syzygium } \\
\text { aromaticu } \\
m\end{array}$ & Indonesia & GT34 & 209 & 194 & 234 & 226 & 294 & 334 & 401 & 444 & 126 & 139 & 182 & 278 & 431 & 157 & 153 & 188 & 229 & 266 & 307 & 264 & 306 & 355 & 389 \\
\hline CMW11424 & C. polychroma & $\begin{array}{l}\text { Syzygium } \\
\text { aromaticu } \\
\mathrm{m}\end{array}$ & Indonesia & GT35 & 209 & 194 & 234 & 226 & 294 & M & 401 & 444 & 126 & 139 & 182 & 278 & 431 & 157 & 153 & 188 & 229 & 266 & 307 & 264 & $\mathrm{~N}$ & 355 & 389 \\
\hline CERC2458 & C. collisensis & $\begin{array}{l}\text { Cunningha } \\
\text { mia } \\
\text { lanceolata }\end{array}$ & FuJian & GT36 & 209 & 200 & 220 & 234 & $\mathrm{~N}$ & 310 & 404 & 444 & 135 & 150 & 177 & 278 & 431 & 171 & 142 & 156 & 227 & 266 & 269 & 283 & 310 & 379 & 397 \\
\hline CERC2459 & C. collisensis & $\begin{array}{l}\text { Cunningha } \\
\text { mia } \\
\text { lanceolata }\end{array}$ & FuJian & GT37 & 209 & 200 & 220 & 234 & $\mathrm{~N}$ & 310 & 404 & 444 & 135 & 150 & 177 & 278 & 431 & 171 & 142 & 156 & 227 & 266 & 269 & 283 & M & 379 & 397 \\
\hline CERC2466 & C. collisensis & $\begin{array}{l}\text { Cunningha } \\
\text { mia } \\
\text { lanceolata }\end{array}$ & FuJian & GT38 & 209 & 200 & 220 & 234 & $\mathrm{~N}$ & 310 & 404 & 444 & 135 & 162 & 177 & 278 & 407 & 171 & 142 & 156 & 227 & 266 & 269 & 283 & $\mathrm{~N}$ & 379 & 397 \\
\hline
\end{tabular}




\begin{tabular}{|c|c|c|c|c|c|c|c|c|c|c|c|c|c|c|c|c|c|c|c|c|c|c|c|c|c|c|c|}
\hline CERC2467 & C. collisensis & $\begin{array}{l}\text { Cunningha } \\
\text { mia } \\
\text { lanceolata }\end{array}$ & FuJian & GT38 & 209 & 200 & 220 & 234 & $\mathrm{~N}$ & 310 & 404 & 444 & 135 & 162 & 177 & 278 & 407 & 171 & 142 & 156 & 227 & 266 & 269 & 283 & $\mathrm{~N}$ & 379 & 397 \\
\hline CMW23809 & C. polyconidia & $\begin{array}{l}\text { Acacia } \\
\text { mearnsii }\end{array}$ & South Africa & GT39 & 201 & 218 & 252 & 250 & 300 & 325 & 412 & 450 & 135 & 211 & 216 & 291 & 405 & 157 & 175 & 180 & 261 & 266 & 316 & M & 306 & 379 & 397 \\
\hline CMW23818 & C. polyconidia & $\begin{array}{l}\text { Acacia } \\
\text { mearnsii }\end{array}$ & South Africa & GT40 & 201 & 218 & 252 & 250 & 300 & 325 & 412 & 450 & 135 & 211 & 216 & 291 & 405 & 157 & 175 & 180 & 261 & 266 & 316 & M & 310 & 379 & 397 \\
\hline CMW38543 & C. ficicola & $\begin{array}{l}\text { Ficus } \\
\text { carica }\end{array}$ & Japan & GT41 & 201 & 191 & 231 & 238 & 273 & 320 & 407 & 460 & 138 & 127 & 172 & 278 & 455 & 157 & 160 & 165 & $\mathrm{~N}$ & 270 & 287 & 280 & 303 & 355 & 397 \\
\hline CMW38544 & C. ficicola & $\begin{array}{l}\text { Ficus } \\
\text { carica }\end{array}$ & Japan & GT41 & 201 & 191 & 231 & 238 & 273 & 320 & 407 & 460 & 138 & 127 & 172 & 278 & 455 & 157 & 160 & 165 & $\mathrm{~N}$ & 270 & 287 & 280 & 303 & 355 & 397 \\
\hline CMW29120 & C. corymbiicola & $\begin{array}{l}\text { Corymbia } \\
\text { variegata }\end{array}$ & Australia & & M & M & M & M & 270 & M & M & M & 135 & M & M & M & M & 157 & M & M & 261 & 266 & M & M & 310 & M & 397 \\
\hline CMW29349 & C. corymbiicola & $\begin{array}{l}\text { Eucalyptus } \\
\text { pilularis }\end{array}$ & Australia & & M & M & M & M & 270 & M & M & M & 135 & M & M & M & M & 157 & M & M & 261 & 266 & M & M & 310 & M & 397 \\
\hline
\end{tabular}

${ }^{1} \mathrm{~N}=$ Missing data

${ }^{2} \mathrm{M}=$ Multiple Allele

${ }^{3}$ Identified as $C$. changhui in this study 
Supplementary Table 2 Microsatellite summary statistics, including allele frequencies and private alleles of Ceratocystis species in Asian-Astralian Clade recovered from 23 microsatellite markers

\begin{tabular}{|c|c|c|c|c|c|c|c|c|c|c|c|c|}
\hline Locus & $\begin{array}{l}\text { Allele } \\
\text { size }\end{array}$ & $\begin{array}{l}\text { C. } \\
\text { cercfa } \\
\text { biensis } \\
\mathrm{N}=40\end{array}$ & $\begin{array}{l}\text { C. } \\
\text { chan } \\
\text { ghui } \\
\mathrm{N}=37\end{array}$ & $\begin{array}{l}\text { C. uchi } \\
\text { dae } \\
\mathrm{N}=2\end{array}$ & $\begin{array}{l}\text { C. } \\
\text { atrox } \\
\mathrm{N}=2\end{array}$ & $\begin{array}{l}\text { C. piril } \\
\text { liformis } \\
\mathrm{N}=2\end{array}$ & $\begin{array}{l}\text { C. obpy } \\
\text { riformis } \\
\mathrm{N}=2\end{array}$ & $\begin{array}{l}C . \\
\text { larium } \\
\mathrm{N}=2\end{array}$ & $\begin{array}{l}\text { C. poly } \\
\text { chroma } \\
\mathrm{N}=2\end{array}$ & $\begin{array}{l}\text { C. } \\
\text { collis } \\
\text { ensis } \\
\mathrm{N}=4\end{array}$ & $\begin{array}{l}\text { C. poly } \\
\text { conidia } \\
\mathrm{N}=2\end{array}$ & $\begin{array}{l}\text { C. fici } \\
\text { cola } \\
\mathrm{N}=2\end{array}$ \\
\hline \multirow{9}{*}{$\mathrm{AF} 2$} & 192 & & & & 1.000 & 0.500 & 1.000 & & & & & \\
\hline & 201 & & & & & & & & & & 1.000 & 1.000 \\
\hline & 203 & 0.150 & & & & & & 1.000 & & & & \\
\hline & 206 & 0.850 & & & & 0.500 & & & & & & \\
\hline & 209 & & & & & & & & 1.000 & 1.000 & & \\
\hline & $219^{\mathrm{a}}$ & & & 1.000 & & & & & & & & \\
\hline & $220^{\mathrm{a}}$ & & 0.378 & & & & & & & & & \\
\hline & $223^{\mathrm{a}}$ & & 0.459 & & & & & & & & & \\
\hline & $232^{\mathrm{a}}$ & & 0.162 & & & & & & & & & \\
\hline \multirow[t]{4}{*}{ AF3 } & $191^{\mathrm{a}}$ & & & & & & & & & & & 1.000 \\
\hline & 194 & 1.000 & 1.000 & 1.000 & 1.000 & 1.000 & 1.000 & 1.000 & 1.000 & & & \\
\hline & $200^{\mathrm{a}}$ & & & & & & & & & 1.000 & & \\
\hline & $218^{\mathrm{a}}$ & & & & & & & & & & 1.000 & \\
\hline \multirow[t]{10}{*}{ AF4 } & $218^{\mathrm{a}}$ & & & & & & & 1.000 & & & & \\
\hline & $220^{\mathrm{a}}$ & & & & & & & & & 1.000 & & \\
\hline & $228^{\mathrm{a}}$ & & & & & & 1.000 & & & & & \\
\hline & 231 & & & & 1.000 & 0.500 & & & & & & 1.000 \\
\hline & 234 & & & & & 0.500 & & & 1.000 & & & \\
\hline & 237 & 0.750 & 0.378 & & & & & & & & & \\
\hline & $240^{\mathrm{a}}$ & 0.250 & & & & & & & & & & \\
\hline & $243^{\mathrm{a}}$ & & 0.622 & & & & & & & & & \\
\hline & $249^{\mathrm{a}}$ & & & 1.000 & & & & & & & & \\
\hline & $252^{\mathrm{a}}$ & & & & & & & & & & 1.000 & \\
\hline \multirow[t]{5}{*}{ AF5 } & 226 & 1.000 & 1.000 & 1.000 & 1.000 & & & & 1.000 & & & \\
\hline & 230 & & & & & 1.000 & 1.000 & & & & & \\
\hline & 234 & & & & & & & 1.000 & & 1.000 & & \\
\hline & $238^{\mathrm{a}}$ & & & & & & & & & & & 1.000 \\
\hline & $250^{\mathrm{a}}$ & & & & & & & & & & 1.000 & \\
\hline AF6 & $252^{\mathrm{a}}$ & & & & & & 1.000 & & & & & \\
\hline
\end{tabular}




\begin{tabular}{|c|c|c|c|c|c|c|c|c|c|c|c|c|}
\hline & 270 & & 1.000 & 1.000 & 1.000 & 1.000 & & 0.500 & & & & \\
\hline & $273^{\mathrm{a}}$ & & & & & & & & & & & 1.000 \\
\hline & $288^{\mathrm{a}}$ & 0.150 & & & & & & & & & & \\
\hline & $291^{a}$ & 0.075 & & & & & & & & & & \\
\hline & 294 & 0.725 & & & & & & & 1.000 & & & \\
\hline & $300^{\mathrm{a}}$ & & & & & & & & & & 1.000 & \\
\hline & N/A & 0.050 & & & & & & 0.500 & & 1.000 & & \\
\hline AF7 & 310 & & & & & & & 1.000 & & 1.000 & & \\
\hline & $319^{\mathrm{a}}$ & & & & 1.000 & & & & & & & \\
\hline & $320^{\mathrm{a}}$ & & & & & & & & & & & 1.000 \\
\hline & $325^{\mathrm{a}}$ & & & & & & & & & & 1.000 & \\
\hline & 328 & 0.950 & 1.000 & & & & & & & & & \\
\hline & $329^{\mathrm{a}}$ & & & 1.000 & & & & & & & & \\
\hline & 334 & 0.050 & & & & & & & 0.500 & & & \\
\hline & 340 & & & & & 1.000 & 1.000 & & & & & \\
\hline & N/A & & & & & & & & 0.500 & & & \\
\hline AF9 & 399 & & & & & 1.000 & 1.000 & & & & & \\
\hline & 401 & 0.975 & 1.000 & 1.000 & 1.000 & & & & 1.000 & & & \\
\hline & $404^{\mathrm{a}}$ & & & & & & & & & 1.000 & & \\
\hline & $407^{\mathrm{a}}$ & & & & & & & & & & & 1.000 \\
\hline & $412^{\mathrm{a}}$ & & & & & & & & & & 1.000 & \\
\hline & $422^{\mathrm{a}}$ & & & & & & & 1.000 & & & & \\
\hline & N/A & 0.025 & & & & & & & & & & \\
\hline AF11 & 444 & 0.950 & 1.000 & 1.000 & & & & & 1.000 & 1.000 & & \\
\hline & $447^{\mathrm{a}}$ & 0.050 & & & & & & & & & & \\
\hline & 450 & & & & & 1.000 & 0.500 & & & & 1.000 & \\
\hline & 452 & & & & 1.000 & & 0.500 & & & & & \\
\hline & $460^{\mathrm{a}}$ & & & & & & & & & & & 1.000 \\
\hline & $476^{\mathrm{a}}$ & & & & & & & 1.000 & & & & \\
\hline CAA10 & 126 & 0.900 & 1.000 & 1.000 & & 0.500 & 1.000 & & 1.000 & & & \\
\hline & 129 & 0.075 & & & 1.000 & 0.500 & & & & & & \\
\hline & 135 & & & & & & & 1.000 & & 1.000 & 1.000 & \\
\hline & $138^{\mathrm{a}}$ & & & & & & & & & & & 1.000 \\
\hline & N/A & 0.025 & & & & & & & & & & \\
\hline CAA38 & 93 & & & & & 1.000 & 1.000 & & & & & \\
\hline & $124^{\mathrm{a}}$ & & & & 1.000 & & & & & & & \\
\hline & $127^{\mathrm{a}}$ & & & & & & & & & & & 1.000 \\
\hline & $130^{\mathrm{a}}$ & & & & & & & 1.000 & & & & \\
\hline
\end{tabular}




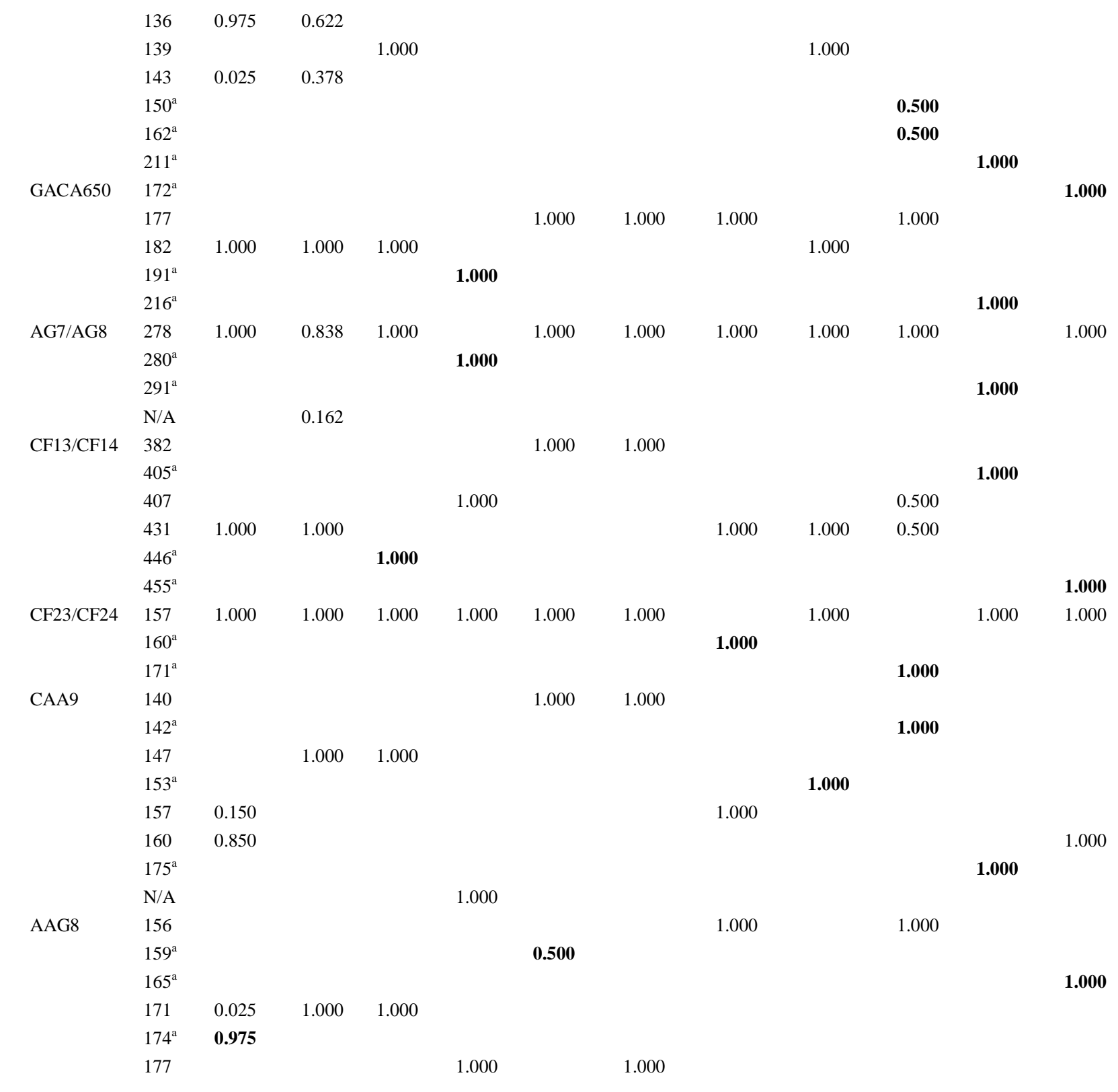




\begin{tabular}{|c|c|c|c|c|c|c|c|c|c|c|c|c|}
\hline & $180^{\mathrm{a}}$ & & & & & & & & & & 1.000 & \\
\hline & $183^{\mathrm{a}}$ & & & & & 0.500 & & & & & & \\
\hline & $188^{\mathrm{a}}$ & & & & & & & & 1.000 & & & \\
\hline \multirow[t]{8}{*}{ CAT1 } & 219 & & & & & 1.000 & 1.000 & & & & & \\
\hline & $221^{a}$ & & & & & & & 1.000 & & & & \\
\hline & $225^{\mathrm{a}}$ & & & & 1.000 & & & & & & & \\
\hline & $227^{\mathrm{a}}$ & & & & & & & & & 1.000 & & \\
\hline & $229^{\mathrm{a}}$ & & & & & & & & 1.000 & & & \\
\hline & 232 & 1.000 & 1.000 & 1.000 & & & & & & & & \\
\hline & $261^{a}$ & & & & & & & & & & 1.000 & \\
\hline & N/A & & & & & & & & & & & 1.000 \\
\hline \multirow[t]{2}{*}{ AG1/AG2 } & 266 & 1.000 & 1.000 & 1.000 & 1.000 & 1.000 & 1.000 & 1.000 & 1.000 & 1.000 & 1.000 & \\
\hline & $270^{\mathrm{a}}$ & & & & & & & & & & & 1.000 \\
\hline \multirow[t]{9}{*}{ CAA80 } & $263^{\mathrm{a}}$ & & & & & & & 1.000 & & & & \\
\hline & $269^{a}$ & & & & & & & & & 1.000 & & \\
\hline & $280^{\mathrm{a}}$ & & & & 1.000 & & & & & & & \\
\hline & $284^{a}$ & & & 1.000 & & & & & & & & \\
\hline & $287^{\mathrm{a}}$ & & & & & & & & & & & 1.000 \\
\hline & $292^{\mathrm{a}}$ & & 0.622 & & & & & & & & & \\
\hline & 304 & 1.000 & 0.378 & & & 1.000 & 1.000 & & & & & \\
\hline & $307^{\mathrm{a}}$ & & & & & & & & 1.000 & & & \\
\hline & $316^{\mathrm{a}}$ & & & & & & & & & & 1.000 & \\
\hline \multirow[t]{6}{*}{ CAT9X } & $264^{a}$ & & & & & & & & 1.000 & & & \\
\hline & 267 & & 1.000 & 1.000 & & 1.000 & & & & & & \\
\hline & 270 & 1.000 & & & 1.000 & & 1.000 & & & & & \\
\hline & $280^{\mathrm{a}}$ & & & & & & & & & & & 1.000 \\
\hline & 283 & & & & & & & 1.000 & & 1.000 & & \\
\hline & N/A & & & & & & & & & & 1.000 & \\
\hline \multirow[t]{6}{*}{ САТЗK } & $303^{\mathrm{a}}$ & & & & & & & & & & & 1.000 \\
\hline & 306 & 0.950 & 0.919 & 1.000 & 1.000 & 1.000 & 1.000 & & 0.500 & & 0.500 & \\
\hline & 310 & & & & & & & & & 0.250 & 0.500 & \\
\hline & $319^{\mathrm{a}}$ & & & & & & & 0.500 & & & & \\
\hline & $322^{\mathrm{a}}$ & & 0.027 & & & & & & & & & \\
\hline & N/A & 0.050 & 0.054 & & & & & 0.500 & 0.500 & 0.750 & & \\
\hline \multirow[t]{3}{*}{ CAT1200 } & 355 & 1.000 & 1.000 & 1.000 & 1.000 & & & & 1.000 & & & 1.000 \\
\hline & 357 & & & & & 1.000 & 1.000 & & & & & \\
\hline & 379 & & & & & & & 1.000 & & 1.000 & 1.000 & \\
\hline AAG9 & 384 & 0.025 & & & & 1.000 & 1.000 & & & & & \\
\hline
\end{tabular}




\begin{tabular}{|c|c|c|c|c|c|c|c|c|}
\hline $386^{\mathrm{a}}$ & & & 1.000 & & & & & \\
\hline 389 & 0.050 & & & & 1.000 & & & \\
\hline 392 & 0.900 & 0.919 & 1.000 & & & & & \\
\hline 397 & 0.025 & 0.081 & & & & 1.000 & 1.000 & 1.000 \\
\hline $401^{\mathrm{a}}$ & & & & 1.000 & & & & \\
\hline
\end{tabular}

$\mathrm{N}$ : Sample size

N/A: Missing data

Allele size $\mathrm{a}^{\mathrm{a}}$ and number is bold: Private allele 